\title{
Curcumin: a therapeutic strategy in cancers by inhibiting the canonical WNT/ $\beta$-catenin pathway
}

\author{
Alexandre Vallée ${ }^{1 *}$, Yves Lecarpentier ${ }^{2}$ and Jean-Noël Vallée $e^{3,4}$
}

\begin{abstract}
Numerous studies have presented that curcumin could have a positive effect in the prevention of cancer and then in tumor therapy. Several hypotheses have highlighted that curcumin could decreases tumor growth and invasion by acting on both chronic inflammation and oxidative stress. This review focuses on the interest of use curcumin in cancer therapy by acting on the WNT/ $\beta$-catenin pathway to repress chronic inflammation and oxidative stress. In the cancer process, one of the major signaling pathways involved is the WNT/ $\beta$-catenin pathway, which appears to be upregulated. Curcumin administration participates to the downregulation of the WNT/ $\beta$-catenin pathway and thus, through this action, in tumor growth control. Curcumin act as PPARY agonists. The WNT/ $\beta$-catenin pathway and PPARY act in an opposed manner. Chronic inflammation, oxidative stress and circadian clock disruption are common and co-substantial pathological processes accompanying and promoting cancers. Circadian clock disruption related to the upregulation of the WNT/ $\beta$-catenin pathway is involved in cancers. By stimulating PPARY expression, curcumin can control circadian clocks through the regulation of many key circadian genes. The administration of curcumin in cancer treatment would thus appear to be an interesting therapeutic strategy, which acts through their role in regulating WNT/ß-catenin pathway and PPARY activity levels.
\end{abstract}

Keywords: Curcumin, Cancer, WNT pathway, Inflammation, Oxidative stress, PPARY

\section{Background}

The complex process of cancer can be defined in terms of three stages: initiation, promotion and progression [1-3]. Many cancers are initiated by chronic inflammation, involving numerous physical, chemical and biological determinants [4]. Several studies have examined the relationship between chronic inflammation and cancer $[5,6]$ and indeed have highlighted the promising role of anti-inflammatory treatments for cancer [7]. Chronic inflammation is responsible for the different stages observed in cancers, such as invasion, angiogenesis, proliferation and metastasis [8-10].

In parallel, oxidative stress promotes DNA damages in cancers [11]. Since few years, the combination formed by oxidative stress and chronic inflammation is involved

\footnotetext{
* Correspondence: alexandre.g.vallee@gmail.com

${ }^{1}$ Diagnosis and Therapeutic Center, Hypertension and Cardiovascular Prevention Unit, Hotel-Dieu Hospital, AP-HP, Université Paris Descartes, 1 place du Parvis de Notre-Dame, Paris, France

Full list of author information is available at the end of the article
}

in the initiation of cancer [12]. Reactive oxygen species production (ROS) is increased by the activation of inflammatory factors [13] and thus also participates in the process of invasion, proliferation, angiogenesis and then metastasis [14]. The canonical $\mathrm{WNT} / \beta$-catenin pathway controls several other pathways involved in development and tissue homeostasis. This pathway is regulated from transcription-level regulations to post-transcriptional modifications. An aberrant $\mathrm{WNT} / \beta$-catenin pathway is generally observed in cancers and leads to inflammation and oxidative stress $[12,15]$.

The recent therapeutic strategies in cancer are associated with several limitations, such as high risk of relapse, drug resistance, poor outcomes and unavailability of therapy. However, plants are the site of promise sources of bioactive natural components [16]. These natural compounds could be interesting and novels strategies in therapy. Curcumin (1,7-bis (4-hydroxy-3-methoxyphenyl)1,6-heptadiene-3,5-dione) is a natural product which occurs polyphenolic phytochemical properties from the

(c) The Author(s). 2019 Open Access This article is distributed under the terms of the Creative Commons Attribution 4.0 International License (http://creativecommons.org/licenses/by/4.0/), which permits unrestricted use, distribution, and 
rhizome of the Curcuma longa L. [17]. Curcumin has been discovered in 1815 by Vogel and Pelletier [18]. Its yellowcolored hydrophobic component is traditionally used in Asian countries for its several properties against pathophysiological states including anticancer [19]. Several targets of curcumin have been shown to have chemotherapeutical properties. Curcumin use may have a major role in the control of inflammation, angiogenesis, metastasis and proliferation [20]. Curcumin can downregulate numerous pathways, such as nuclear factor- $x$ B (NF- $x \mathrm{~B})$, cyclooxygenase- 2 (COX-2), and the canonical WNT/ $\beta$-catenin pathway [20].

The chronic inflammatory microenvironment of tumors could be targeted by curcumin. It is well known that the human body is capable of self-healing after a short-term inflammatory response, but a long-term chronic inflammation could lead to initiation of the cancer process. Many studies have shown that inflammatory factors (including interleukins, TNF- $\alpha, \mathrm{NF}-\varkappa \mathrm{B}$ ) and the ROS production-induced inflammation infiltrate the inflammatory microenvironment leading to DNA damages and ultimately initiation of cancer [21]. By acting on several signaling pathways, especially the $\mathrm{WNT} / \beta$-catenin pathway, curcumin can have anticancer effect by inhibiting chronic inflammation and oxidative stress [22].

Curcumin acts as peroxisome proliferator-activated receptor gamma (PPAR $\gamma$ ) agonists and thus downregulate the aberrant $\mathrm{WNT} / \beta$-catenin pathway observed in cancers [23]. PPAR $\gamma$ agonists offer an interesting therapeutic solution in cancers by acting on both oxidative stress and inflammation [24, 25]. Indeed, in several tissues, overactivation of the canonical $\mathrm{WNT} / \beta$-catenin pathway induces the downregulation of PPAR $\gamma$, while PPAR $\gamma$ activation induces inhibition of canonical WNT/ $\beta$-catenin pathway. In mainly cancers, the canonical $\mathrm{WNT} / \beta$-catenin pathway is increased while PPAR $\gamma$ is downregulated [12].

In parallel, dysregulation of circadian rhythms (CRs) has been observed in cancers [26]. This dysfunction leads to the upregulation of the canonical $\mathrm{WNT} / \beta$-catenin pathway contributing to cancer initiation. PPAR $\gamma$ can control CRs by regulating many key circadian genes, like Bmal1 (brain and muscle aryl-hydrocarbon receptor nuclear translocator-like 1) [27] and then can target WNT pathway [28].

This review focuses on the interest of use curcumin in cancer therapy by acting through the opposed interaction between the canonical WNT/ $\beta$-catenin pathway and PPAR $\gamma$ to repress chronic inflammation and oxidative stress, and to control circadian rhythms.

\section{Curcumin: a new agent for therapeutic strategy in cancers}

Phytotherapy has claimed importance globally in cancer therapies (Table 1). Curcumin, defined as bis- $\alpha, \beta$-unsaturated $\beta$-diketone, is a natural component well documented since 1815. Curcumin is the active compound of turmeric or Curcuma longa L. and presents surprising wide range of beneficial properties, such as anticancer, chemopreventive and chemotherapeutic activities [43]. The health benefits of curcumin are limited by its poor oral bioavailability which can be attributed to the poor absorption, high rate of metabolism and rapid systemic elimination from body. Indeed, curcumin is converted to its water-soluble metabolites and then excreted through urine. This metabolism is composed by two steps. First, a NADPH-dependent metabolism of reduction which comprises the reduction of the double bonds of the heptadiene-3, 5-dione structure catalyzed by NADPH-dependent curcumin reductase. Secondly, a

Table 1 Curcumin an anticancer agent in several tumors

\begin{tabular}{|c|c|c|c|}
\hline Type of cancer & Actions & Type of study & References \\
\hline Benign prostatic hypertrophy & Improved quality of life, reduced symptoms & Pilot product evaluation study & [29] \\
\hline Breast & Inhibition cancer progression, decreased levels of VEGF & Phase I clinical trial & {$[30]$} \\
\hline Chronic myeloid leukemia & Reduction of nitric oxide levels & Randomized controlled trial & {$[31]$} \\
\hline Colorectal & Decrease inflammation (TNF-a), increase p53 & Phase I clinical trial & {$[32]$} \\
\hline Colorectal & Reduction in tumor growth & Phase I clinical trial & [33] \\
\hline Colorectal & Decrease PGE2 levels & Phase I clinical trial & [34] \\
\hline Colon carcinoma & Growth inhibition & Randomized controlled trial & {$[35]$} \\
\hline Intestinal adenoma & Diminution of adverse effects & Randomized controlled trial & {$[36]$} \\
\hline Pancreatic & Inhibition of toxicity profile of tumors & Phase II clinical trial & {$[37]$} \\
\hline Pancreatic & Diminution of NF- $x$ B pathway & Phase I clinical trial & [38] \\
\hline Prostate & Increase survival & Randomized controlled trial & [39] \\
\hline Prostate & Enhanced antiproliferative efficacy and targeting & Randomized controlled trial & [40] \\
\hline Ovarian carcinoma & Increased cytotoxicity & Randomized controlled trial & [41] \\
\hline Head and neck squamous cell carcinoma & Decrease inflammatory mediators & Randomized controlled trial & [42] \\
\hline
\end{tabular}


process of conjugation has been observed with monoglucuronide via a $\beta$-glucuronidase. These two mechanisms are responsible for the low solubility and rapid metabolism of curcumin.

Even if some studies have related that pharmacokinetics of curcumin have revealed poor bioavailability [44], strong pharmacological and clinical applications have been reported for curcumin [45]. Nevertheless, some of possible ways to overcome this poor bioavailability can be counteract by centering on these aspects. Strategies can improve this bioavailability, such as phospholipid complexes, liposomes and nanoparticles. Some polymers have been used to prepare nanoformulations for curcumin drug delivery to improve its biological activity [46]. Biocompatible and biodegradable polymers are utilized in drug delivery systems due to their lower risks of toxicity [47]. Advances in liposomes formulations results in the improvement of therapy for drug-resistant tumors and in the reduction of toxicity [48]. Liposomes consist of phospholipid bilayer shells and aqueous cores resulting in a curcumin encapsulation by both hydrophobic and hydrophilic components. Other curcumin delivery systems are used, as nanogels [49], peptide and protein formulations [50] and cyclodextrin complexes [51].

\section{Chronic inflammation and oxidative stress in cancer process \\ Chronic inflammation}

Numerous studies have presented that chronic inflammation leads to DNA damages and tissue injury [52]. Chronic inflammation impairs cell homeostasis, metabolism to initiate cancer [53]. Moreover, DNA damages involved by the chronic inflammation provides a point of origin for the initiation of malignancy sites. Several studies have well described the link between cancer and chronic inflammation [12]. Chronic inflammation activates ROS and reactive nitrogen species (RNS) production leading to DNA damages [54]. Thus, genomic instabilities are initiated by DNA damages and then cause cancer initiation. Numerous sites of common pathogenic infections are related to cancer initiation [55].

The immune system is also regulated by several inflammatory factors, such as tumor necrosis factor $\alpha$ (TNF- $\alpha$ ), interleukin-6 (IL-6), vascular endothelial growth factor (VEGF) and tumor growth factor- $\beta$ (TGF$\beta)$ [56]. TNF- $\alpha$ expression leads to DNA damages and cytokines stimulation (such as IL-17 [57]), which are responsible for tumor growth, invasion and angiogenesis [58]. Interleukins, IL6 and IL-17, activate the signal transducer and activator transcription (STAT) signaling involved in the cancer process [59].

Chronic inflammation is also responsible for an increase in cyclooxygenase 2 (COX-2, a prostaglandinendoperoxidase synthase). Numerous cytokines (TNF- $\alpha$, IL-1) activate COX-2 [60]. COX-2 stimulates ROS and
RNS production [61, 62]. Nuclear factor- $x \mathrm{~B}(\mathrm{NF}-\varkappa \mathrm{B})$ stimulates several pro-inflammatory factors that activate COX-2 and inducible nitric oxide synthase (iNOS) [53]. $\mathrm{NF}-x \mathrm{~B}$ is one of the major factors involved in chronic inflammation in the cancer process [53]. Several studies have shown that NF- $x \mathrm{~B}$ stimulates the expression of TNF- $\alpha$, IL-6, IL-8, STAT3, COX-2, BCL-2 (B-cell lymphoma 2), metalloproteinases (MMPs), VEGF [53], and thus the ROS production [63]. Il-6 and VEGF activates STAT-3 pathway involved in proliferation, angiogenesis and metastasis [64]. Several cancers presents an over-activation of the STAT-3 pathway [65]. Furthermore, iNOS, an enzyme catalyzing nitric oxide (NO), is activated during chronic inflammation and increases p53 gene mutations [60].

\section{Oxidative stress}

Oxidative stress is considered as an imbalance between the production and elimination of ROS and RNS [11, 66]. ROS production is enhanced by cell damages from oxidation and nitration of macromolecules, such as RNA, DNA, proteins and lipids.

The NADPH oxidase (NOX) enzyme increases ROS production through the oxidation of intracellular NADPH to $\mathrm{NADP}^{+}$. Superoxide anion is then produced, and molecular oxygen phenomenon is reduced due to the transfer of electron through the mitochondrial membrane.

ROS production has a key role in numerous signaling involved in changes of microenvironment [67]. Thus, dysfunction in the respiratory chain of mitochondria is responsible for ROS production [68]. The inflammation observed, where there are damages, involves the uptake of oxygen leading in the release of ROS and its accumulation. NF- $\varkappa$ B, STAT, hypoxia-inducible factors (HIF) and both activator protein-1 (AP-1) play a major role in the stimulation of this process [53]. Moreover, in a vicious circle COX-2, TNF- $\alpha$, IL-6, iNOS are induced by oxidative stress [62]. NADPH-oxidase (NOX) is activated by chronic inflammation resulting in oxidative stress and alteration of the nuclear signaling [69].

\section{Interactions between oxidative stress and inflammation}

(Fig. 1)

Several researches have demonstrated the mechanism by which oxidative stress can lead to chronic inflammation, which in turn could cause cancers [11]. The imbalance caused by oxidative stress leads to damages in the signaling in cells [66]. ROS play a central role both upstream and downstream of the NF- $\mathrm{KB}$ and TNF- $\alpha$ pathways, which are the main mediators of the inflammatory response. The hydroxyl radical is the most harmful of all the ROS. A vicious circle is observed between ROS and these pathways. ROS are generated by NOX system. Moreover, the proteins modified by ROS could result in 


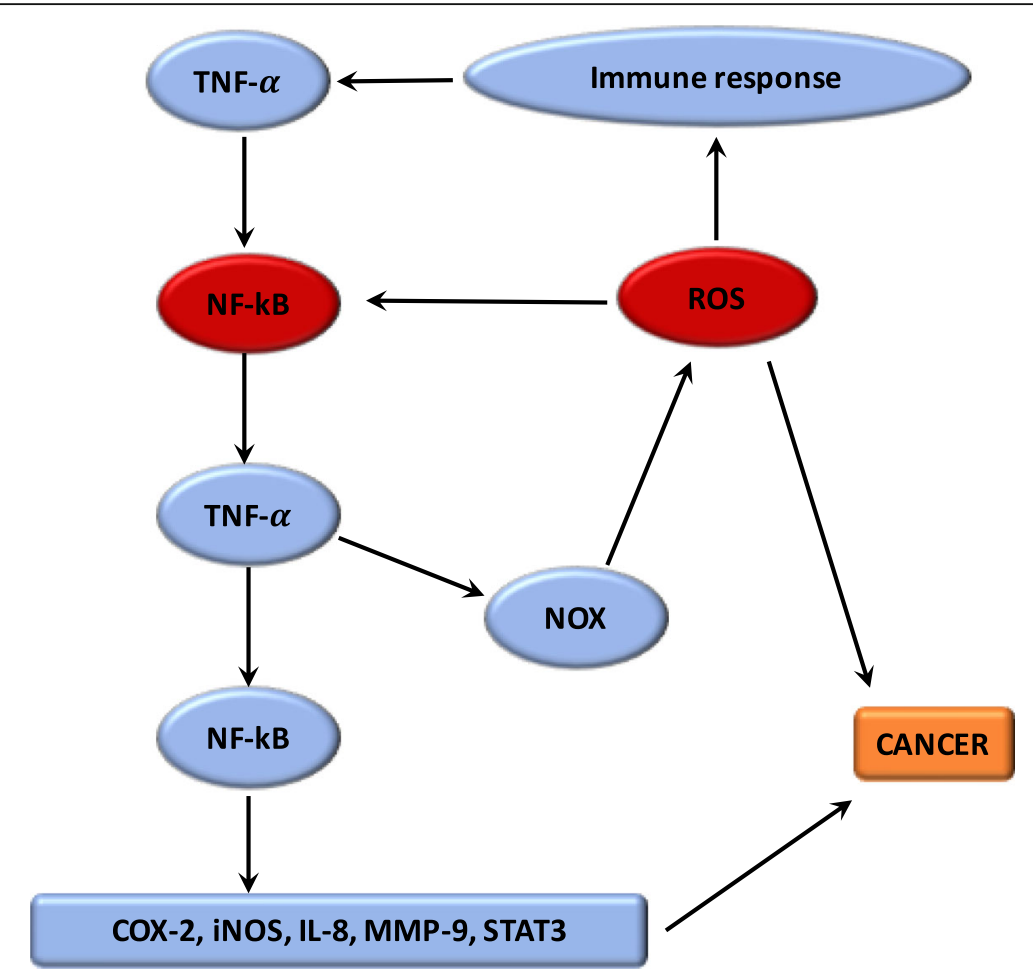

Fig. 1 Relationship between ROS and chronic inflammation

initiation of the auto-immune response to stimulate TNF- $\alpha$ and thus NOX [70]. Nuclear factor erythroid-2 related factor 2 (Nrf2) is mainly associated with oxidative stress in inflammation [11]. Nrf2 is a transcription factor which binds with the antioxidant response element (ARE) [71]. The protective role of Nrf2 in cancer relates to its capability to reduce inflammation and oxidative stress [72]. Several studies have shown that Nrf2 can play an anti-inflammatory role by regulating MAPK (Mitogen-activated protein kinases), NF- $x \mathrm{~B}$, and PI3K pathways [73]. Thus, Nrf2 may play a major role in reducing oxidative damages [74]. Evidence also suggested that mitochondrial dysregulation has a significant role in the cancer mechanism [11].

\section{The WNT pathway, chronic inflammation and oxidative stress}

Many studies have shown that canonical the WNT/ $\mathrm{W}$-catenin pathway stimulates inflammation [52]. Moreover, infection pathogens activate the $\mathrm{WNT} / \beta$-catenin pathway enhancing thereby inflammation. ROS, stimulated by NOX, activates the canonical WNT/ $\beta$-catenin pathway through the oxidization and inactivation of the nucleoredoxin (a redox-sensitive regulator), thus stimulating the cancer process [53]. ROS production leads to the activation of c-Myc, STAT, phosphatidylinositol-3-kinase (PI3K/ Akt) and the inhibition of PPARY [75]. ROS production stimulates the Akt signaling by inhibiting the phosphatase and tensin homolog deleted from chromosome (PTEN) [76]. Moreover, the canonical WNT/ $\beta$-catenin pathway may thus play a major role in cancer by modulating both oxidative stress and inflammation [12].

The canonical WNT/ $\beta$-catenin pathway: a major factor in cancer process (Fig. 2)

WNT name is derived from Wingless Drosophila melanogaster and its mouse homolog Int. The WNT pathway is involved in several signaling and regulating pathways, such as embryogenesis, cell proliferation, migration and polarity, apoptosis, and organogenesis [77]. During the adult stage, the WNT pathway is non-activated or silent. However, during numerous mechanisms and pathologies, such as inflammatory, metabolic and neurological disorders, and cancers, the WNT pathway may become dysregulated [78]. Recent studies have used the WNT pathway for cell therapy-bioengineering processes [79].

WNT ligands are lipoproteins that activate specific coreceptors. These WNT ligands activate the canonical WNT pathway through the action of $\beta$-catenin. WNT ligands activate Frizzled (FZD) receptors and low-density lipoprotein receptor-related protein 5 and 6 (LRP 5/6) [80]. The complex formed by extracellular WNT ligands and FZD/LRP5/6 stimulates intracellular Disheveled (DSH). This activation inactivates the destruction complex of $\beta$-catenin in the cytosol. B-catenin accumulates in the cytosol and then translocates into the nucleus. 


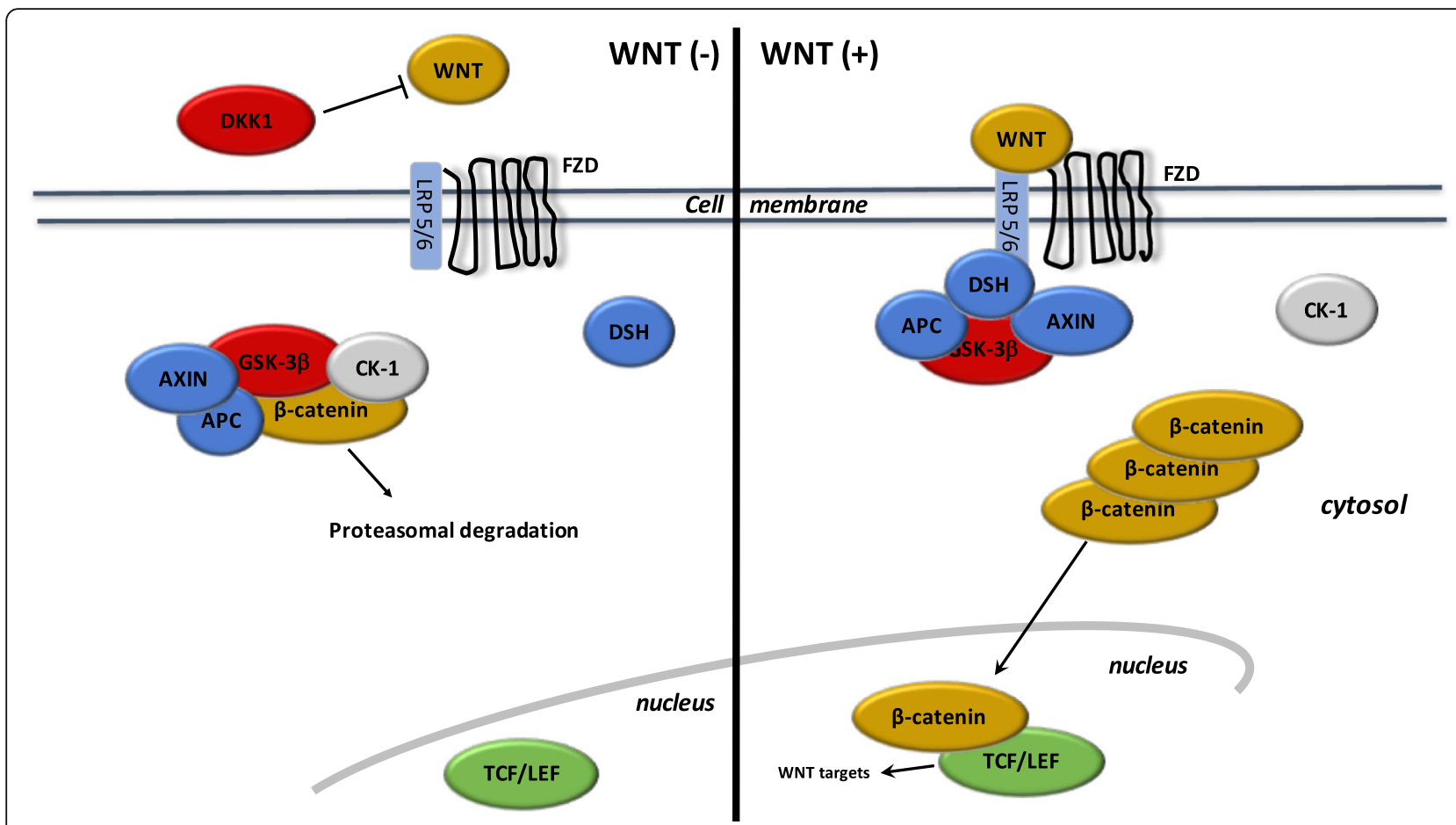

Fig. 2 The canonical WNT/ $\beta$-catenin pathway. WNT (-). Under resting condition, the cytoplasmic $\beta$-catenin is bound to its destruction complex, consisting of APC, AXIN and GSK-3 $\beta$. After CK-1 phosphorylates on Ser45 residue, $\beta$-catenin is further phosphorylated on Thr41, Ser37, and Ser33 residues by GSK-3 $\beta$. Then, phosphorylated $\beta$-catenin is degraded into the proteasome. Therefore, the cytosolic level of $\beta$-catenin is kept low in the absence of WNT ligands. If $\beta$-catenin is not present in the nucleus, the TCF/LEF complex cannot activate the target genes. DKK1 inhibits the WNT/B-catenin pathway by binding to WNT ligands or LRP5/6. WNT (+). When WNT ligands bind to both FZD and LRP5/6, DSH is recruited and phosphorylated by FZD. Phosphorylated DSH in turn recruits AXIN, which dissociates the $\beta$-catenin destruction complex. Therefore, $\beta$-catenin escapes from phosphorylation and subsequently accumulates in the cytosol. The accumulated cytosolic $\beta$-catenin goes into the nucleus, where it binds to TCF/LEF and activates the transcription of target genes

Nuclear $\beta$-catenin interact with T-Cell factor/lymphoid enhancer factor (TCF/LEF) to stimulate gene transcription, such as c-Myc STAT, PI3K/Akt, and cyclin D1 [81].

During the "off-state" of the WNT/ $\beta$-catenin pathway, WNT ligands do not bind FZD and LRP 5/6. The $\beta$-catenin destruction complex, formed by AXIN, APC (adenomatous polyposis coli) and GSK-3 $\beta$ (glycogen synthase kinase $3 \beta$ ), phosphorylates $\beta$-catenin. Thus, phosphorylated $\beta$-catenin is degraded into the proteasome.

Several WNT inhibitors inactivates the canonical WNT/ $\beta$-catenin pathway. GSK-3 $\beta$ is the major inhibitor of the WNT pathway. GSK-3 $\beta$ is a neuron-specific intracellular serine-threonine kinase that regulates several signaling pathways such as inflammation, neuronal polarity and cell membrane signaling [82]. GSK-3 $\beta$ inhibits $\beta$-catenin cytosolic stabilization and nuclear migration. Dickkopf (DKK) and soluble Frizzled-related proteins (SFRP) are also WNT inhibitors and binds FZD, LRP5 and LRP6 [83].

\section{WNT and inflammation in cancers}

Positive interplay between $\mathrm{WNT} / \beta$-catenin and NF- $x \mathrm{~B}$ has been highlighted [84]. The activation of the WNT/ $\beta$ catenin leads to the enhancement of $\mathrm{I} \varkappa \mathrm{B}-\alpha$ (nuclear factor of kappa light polypeptide gene enhancer in B-cells inhibitor, $\alpha)$ degradation and then NF- $\varkappa \mathrm{B}$ stimulation [85]. Stimulation of the target gene, CRD-BP (Coding Region Determinant-Binding Protein, an RNA-binding protein), by activated $\beta$-catenin stabilizes mRNA of $\beta \operatorname{TrCP}$ (Betatransducin repeat-containing protein) [86]. In colon cancer, activation of both $\beta \operatorname{TrCP}$ and CRD-BP is correlated with the stimulation of the $\beta$-catenin and NF- $\varkappa \mathrm{B}$, leading proliferation and metastasis. In breast cancer, TLR3 activation stimulates $\beta$-catenin leading to over-activation of the NF- $\varkappa B$ pathway [87]. Moreover, the $\beta$-catenin and NF- $x B$ pathways stimulates each other in diffuse large B-cell lymphomas [88]. The $\mathrm{WNT} / \beta$-catenin pathway activates COX-2, which then enhances the inflammatory response [89]. E-cadherin and GSK-3 $\beta$ are downregulated in melanoma cells by $\beta$-catenin signaling [90]. Concomitant GSK$3 \beta$ and E-cadherin inhibition with cytosolic $\beta$-catenin accumulation leads to NF- $\varkappa \mathrm{B}$-dependent iNOS expression in hepatic cells [91]. The WNT/ $\beta$-catenin pathway stimulates its target TNFRSF19 in colon cancer, which leads to the activation of the NF- $x$ B signaling [92]. Nevertheless, the observed synergistic interaction between $\beta$-catenin and NF- $\varkappa \mathrm{B}$ depends on the $\beta$-catenin-TCF/LEF link [93]. 
NF- $\varkappa \mathrm{B}$ over-expression inactivates GSK- $3 \beta$ whereas it stimulates $\beta$-catenin signaling $[94,95]$. GSK-3 $\beta$ activation results in the downregulation of TNF- $\alpha$-induced NF- $x \mathrm{~B}$ stimulation in carcinoma cells [94]. I $\mathcal{B} \mathrm{B}$ is stabilized by GSK-3 $\beta$ activation resulting in the downregulation of the $\mathrm{NF}-x \mathrm{~B}$ pathway [95]. NF- $x \mathrm{~B}$ signaling can modulate the

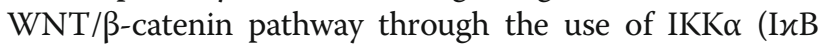
Kinase- $\alpha$ ) and RelA [96]. IKK $\alpha$ stimulates $\beta$-catenin signaling while IKK $\beta$ inhibits $\beta$-catenin signaling [97]. IKK $\alpha$ activates the $\beta$-catenin/TCF/LEF link [98]. Activation of IKK $\alpha$ leads to the cytosolic $\beta$-catenin accumulation resulting in GSK3- $\beta$ and APC inactivation [99].

\section{WNT and oxidative stress in cancers}

The over-activated PI3K/Akt pathway observed in the cancer process is stimulated by ROS production [100]. PTEN is the main inhibitor of the PI3K/Akt pathway [101]. NADPH oxidase and superoxide dismutase oxidize PTEN to inhibit it. Inhibition of PTEN leads to an increase in Akt activity, which enhances the phosphorylation of GSK-3 $\beta$. Thus, GSK-3 $\beta$ inactivated by Akt does not bind $\beta$-catenin. Inactivation of PTEN activates Akt and $\beta$-catenin [102]. Moreover, ROS production participates in the stabilization of HIF- $1 \alpha$ thereby activating glycolytic enzymes [103]. The WNT/ $\beta$-catenin pathway stimulates HIF- $1 \alpha$ by activating the PI3K/Akt pathway [104]. Although this mechanism remains unclear, recent studies have shown that ROS production stimulates the $\mathrm{WNT} / \beta$-catenin pathway [105]. In parallel, Akt [106] and c-Myc [107] enhance ROS production.

\section{PPARY in cancers}

The ligand-activated transcriptional factor peroxisome proliferator receptor $\gamma$ (PPAR $\gamma$ ) is a member of the nuclear hormone receptor super family. It forms a heterodimer with retinoid $\mathrm{X}$ receptor (RXR), leading to a PPAR $\gamma$-RXR complex which binds to specific peroxisome proliferator response element (PPRE) regions in the DNA and activating several target genes involved in fatty acid transport (FABP3), cholesterol metabolism (CYP7A1, LXR $\alpha$, CYP27), glucose homeostasis (PEPCK, GyK) and lipid catabolism (SCD-1). This dimer interacts with other coactivators proteins such as PGC- $1 \alpha$, and induces specific genes expression [108]. Glucose homeostasis, insulin sensitivity, lipid metabolism, immune responses, cell fate and inflammation are regulated by PPAR $\gamma$ activation [109]. Circadian variations of blood pressure and heart rate are regulated by PPAR $\gamma$ through its action on Bmal1 [27]. PPAR $\gamma$ modulates the expression of several genes involved in inflammation, and it decreases the activity of inflammation-related transcription factors such as NF- $x$ B [110]. Several studies have shown decreased PPAR $\gamma$ expression in association with chronic inflammation in cancers [12].

\section{Interplay between PPAR $\gamma$ and the WNT/ $\beta$-catenin pathway in cancers}

The action of PPAR $\gamma$ agonists remains unclear in cancer cells even if their role is well understood in the regulation of differentiation and stemness programs [111]. In physiological cells, PPAR $\gamma$ inhibits tumorigenesis and WNT signaling by targeting phosphorylated $\beta$-catenin at the proteasome through a process that involves its catenin binding domain within PPAR $\gamma$. In contrast, oncogenic $\beta$-catenin counteracts proteasomal degradation by downregulating PPAR $\gamma$ activity, which requires its TCF/ LEF binding domain [112]. In adipocyte cells, PPAR $\gamma$ leads to increased differentiation and a reduction in proliferation by targeting the $\mathrm{WNT} / \beta$-catenin pathway. PPAR $\gamma$ binds with GSK3- $\beta$ to activate the differentiation factor $\mathrm{C} / \mathrm{EBP} \alpha$ leading to the production of adiponectin [113]. PPAR $\gamma$ activation downregulates $\beta$-catenin at both the mRNA and protein levels to induce differentiation [114]. In metastatic prostate cancer LnCaP cells, PPAR $\gamma$ decreases the WNT pathway by affecting phosphorylated $\beta$-catenin in the proteasome $[112,115]$. In colorectal and gastric cancer cells, PPAR $\gamma$ inhibits $\beta$-catenin expression, subcellular localization and downstream effectors, leading to the modulation of numerous genes, such as telomerase reverse transcriptase and Sox9, both of which are involved in cell differentiation and the survival phenomenon [116]. PPAR $\gamma$ agonists, by decreasing the $\mathrm{WNT} / \beta$-catenin pathway, could be used in combination with other drugs such as inhibitors of tyrosine kinases [117], Akt [118], and MAPK cascades to maximize the antitumor and pro-differentiating effect.

\section{Circadian rhythms in cancers}

Circadian rhythms: definition (Fig. 3)

Numerous biological processes in the body are regulated by the circadian "clock" (circadian locomotors output cycles kaput). The circadian clock is in the hypothalamic suprachiasmatic nucleus ( $\mathrm{SCN})$. CRs are endogenous and entrainable free-running periods that last approximately 24h. Numerous transcription factors are responsible for the control of CRs. These are called circadian locomotors output cycles kaput (Clock), brain and muscle aryl-hydrocarbon receptor nuclear translocator-like 1 (Bmal1), Period 1 (Per1), Period 2 (Per2), Period 3 (Per3), and Cryptochrome (Cry 1 and Cry 2) [119, 120]. These transcription factors are subject to positive and negative selfregulation mediated by CRs $[121,122]$. Clock and Bmal1 heterodimerize and thus initiate the transcription of Per1, Per2, Cry1 and Cry2 [123]. The Per/Cry heterodimer can downregulate its stimulation through negative feedback. It translocates back to the nucleus to directly inhibit the Clock/Bmal1 complex and then repress its own transcription [123]. The Clock/Bmal1 heterodimer also stimulates the transcription of retinoic acid-related orphan nuclear 


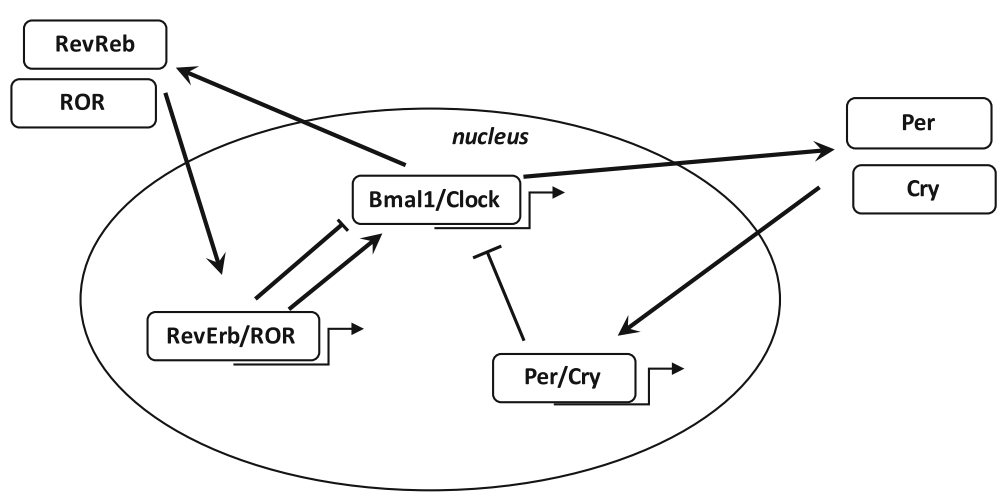

Fig. 3 Circadian clock genes. The clock consists of a stimulatory loop, with the Bmal1/Clock heterodimer stimulating the transcription of Per and Cry genes, and an inhibitory feedback loop with the Per/Cry heterodimer translocating to the nucleus and repressing the transcription of the Clock and Bmal1 genes. An additional loop involves the RORs and RevErbs factors with a positive feedback by ROR and a negative feedback by RevErbs

receptors, Rev-Erbs and retinoid-related orphan receptors (RORs). Through positive feedback RORs can stimulate the transcription of Bmal1, whereas Rev-Erbs can inhibit their transcription through negative feedback [123].

\section{Circadian rhythms disruption in cancers}

Epidemiological and fundamental evidence supports the idea of linking circadian disruption with cancer [26]. DNA repair, apoptosis and cell cycle regulation follow circadian rhythms in humans [124]. Disruption of the CRs is associated with dysregulation in cell proliferation and thus the initiation of cancer [125]. Clock/Bmal1, Per1 and Per2 maintain the rhythmic pattern of cell proliferation and repair of DNA damage [126]. Bmall over-expression has been observed in cell growth of NIH 3 T3 cells [127]. Metastatic cancers present high levels of Clock or Bmal1 genes [128]. Clock over-expression is often associated with cell proliferation in colorectal carcinoma cells [129]. Bmal1 upregulation is found in certain types of pleural mesothelioma while Bmal1 knockdown is associated with reduced cell growth and induced apoptosis [130]. Bmal1 is considered as an attractive target in leukemia cells [131].

\section{Circadian rhythms and inflammation}

Melatonin has been used in the treatment of chronic bowel inflammation resulting in decreasing inflammation through inhibition of COX-2 and iNOS [132]. Moreover, melatonin can act on iNOS and COX-2 by suppressing p52 acetylation and transactivation [133]. Melatonin inhibits NF- $\varkappa \mathrm{B}$ and COX-2 in murine macrophage-like cells [134]. An anti-inflammatory response of melatonin has been observed through a decrease in NF$\kappa B$ activity [135]. Melatonin downregulates the nuclear translocation of NF-kB, leading to an enhancement of anticancer effects in lung cancer [136].

\section{Circadian rhythms and oxidative stress}

Recent studies have indicated that the hypoxic response in cancer could be directly controlled by the circadian rhythm Clock/Bmal1 [137]. In a similar way, blood oxygen levels present daily rhythms influenced by clock genes [138]. Metabolic dysregulation in cancers may results of disruption of Bmal1 in a hypoxic-dependent way [139]. Considerable evidence connects circadian disruption with hormone-dependent diseases, such as breast and prostate cancers. One of the main factors is melatonin, a hormone produced by the pineal gland in a circadian manner to regulate sleep [140]. In the mitochondria, melatonin is linked to the regulation of oxidative stress [141]. Melatonin stimulates the activity of glutathione peroxidase and glutathione reductase [142]. Moreover, melatonin directly regulates the mitochondrial respiratory chain, which modulates ATP production [141]. Furthermore, alteration of melatonin secretion by sleep disruption could increase ROS and RNS production [143].

\section{Interaction between the WNT/B-catenin pathway and circadian rhythms (Fig. 4)}

$\mathrm{WNT} / \beta$-catenin pathway is the downstream target of the RORs control factors and has several putative Bmal1 clock-binding sites within its promoter [144]. Through such interactions, circadian genes can regulate cell cycle progression through the WNT pathway [145]. The WNT pathway can be inhibited by a Bmal1 knockdown [146]. Expression levels of WNT-related genes in wildtype mice are higher than those observed in Bmal1 knockdown mice [147]. Cell proliferation and cell cycle progression are controlled by Bmal1 through the activation of the canonical $\mathrm{WNT} / \beta$-catenin pathway [148]. Bmal1 enhances $\beta$-catenin transcription, inhibits $\beta$-catenin degradation and downregulates GSK-3 $\beta$ activity [149]. Per2 degradation induced by $\beta$-catenin increases 


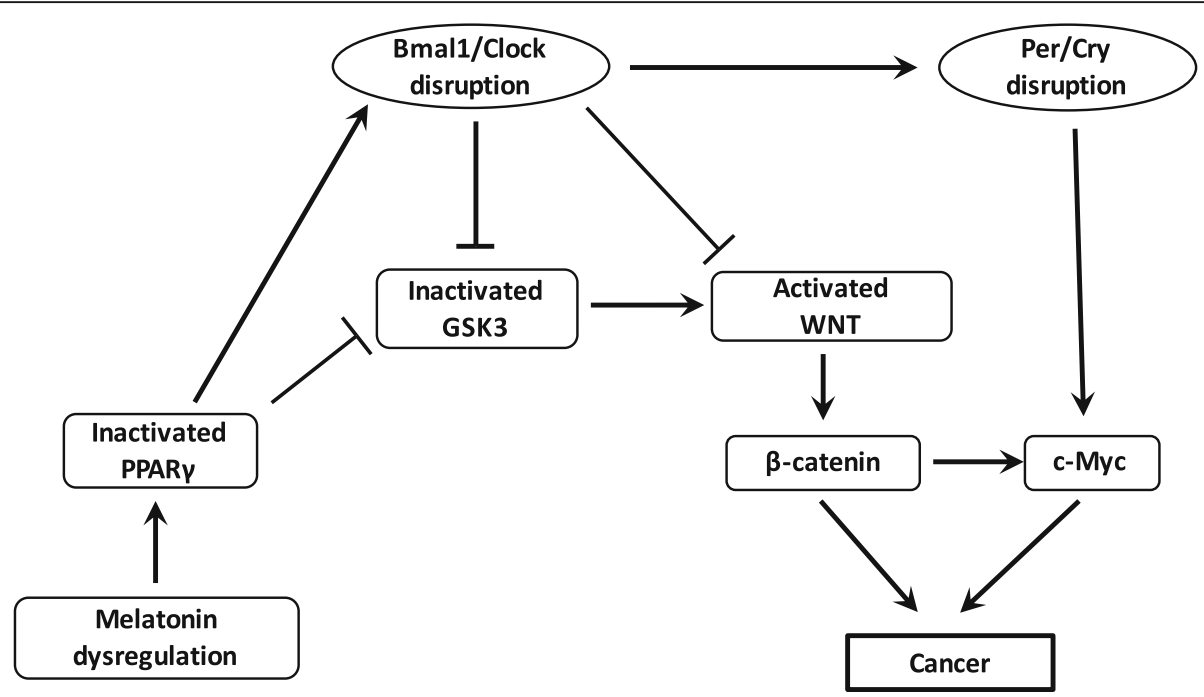

Fig. 4 Interactions between PPARY, WNT pathway and circadian rhythms in cancer. Dysregulation of melatonin and nocturin decreases the expression of PPARy in cancer. Decreased PPARY dysregulates Bmal1/Clock heterodimer. Decreased PPARy expression directly activates the formation of the heterodimer Bmal1/Clock and $\beta$-catenin cytosolic accumulation but inhibits the activity of GSK3, the main inhibitor of the WNT/ $\beta$-catenin pathway. Bmal1/Clock knockout also decreases GSK3 activity and activates the WNT/ $\beta$-catenin pathway and its downstream gene c-Myc through the activation of the heterodimer Per/Cry. The activation of the WNT/ $\beta$-catenin pathway by the cytosolic accumulation of the $\beta$-catenin and the activation of c-Myc lead to cancer initiation (oxidative stress and chronic inflammation)

circadian disruption in the intestinal mucosa of ApcMin/+ mice [150].

In physiological conditions, the core circadian genes work in accurate feedback loops and keep the molecular clockworks in the SCN. They allow the regulation of peripheral clocks [121]. Per1 and Per2 maintain cells circadian rhythm and regulate cell-related genes expression, including $\mathrm{c}-\mathrm{Myc}$, so as to sustain the normal cell cycle [151]. Levels of mRNAs and proteins of circadian genes oscillate throughout the 24 h' period [121].

\section{Action of PPARY on the circadian rhythms (Fig. 4)}

PPAR $\gamma$ acts directly with the core clock genes and presents diurnal variations in liver and blood vessels [27]. In mice, impaired diurnal rhythms are induced by the inhibition of PPAR $\gamma$ [152]. PPAR $\gamma$ agonists can regulate Bmal1 and then the formation of the heterodimer Clock/Bmal1 [27] and can target Rev-Erb [153]. Downregulation of the clock-controlled gene Nocturin inhibits PPARy oscillations in the liver of mice fed on a high-fat diet. In physiological conditions, nocturin binds PPAR $\gamma$ to improve its transcriptional activity [154]. PPAR $\gamma$ deletion alters the circadian function of 15-Deoxy-D 12,14-prostaglandin J2 (15-PGJ2) [152]. The partner of PPAR, RXR, interacts with Clock protein in a ligand-dependent manner and then blocks Clock/Bmall heterodimer formation and transcriptional activity [155]. PPAR $\gamma$ acts on the mammalian clock to control energy metabolism. Circadian metabolism is directly controlled by PPAR $\gamma$ [152]. Retinoic acid receptor-related orphan receptor gamma $t$ (ROR gammat) is considered as a major transcriptional factor for Th17 differentiation [156]. PPAR $\gamma$ can influence the function of Th cells clones [157]. PPARy agonists inhibits Th17 differentiation through the inhibition of ROR gammat induction [158]. CD4+ $\mathrm{T}$ cells fail to express ROR gammat under the action of PPAR $\gamma$ agonists [159].

\section{Curcumin in cancers}

Curcumin, an angiogenesis and metastasis inhibitor (Fig. 5)

Numerous studies have shown that curcumin inhibits the precursors of angiogenesis in cancers [160]. Chemical agonists of curcumin also induces the suppression of angiogenesis [16]. Curcumin downregulates the osteopontin (OPN, a secreted phosphoprotein 1)-induced cells leading to the downregulation of VEGF signaling and then the NF- $\varkappa$ B/AT-4-dependent pathway [161]. Moreover, tetrahydrocurcumin, an analog of curcumin, can decrease the expression of several targets, such as COX-2, VEGF, MMP-9 [162].

The complex process of metastasis involves numerous alterations and degradations of the ECM by MMP which leads to the over-expression of chemokine receptors, inflammation and then angiogenesis. Curcumin inhibits cell migration in colorectal cancer by inhibiting MMP-9 activity and NF- $x \mathrm{~B}$ and in the same time by activating AP-1 [163]. Furthermore, in prostatic cancer, cell migration is inhibited by curcumin which acts by decreasing inflammatory environment through the abolition of proinflammatory cytokines [164]. 


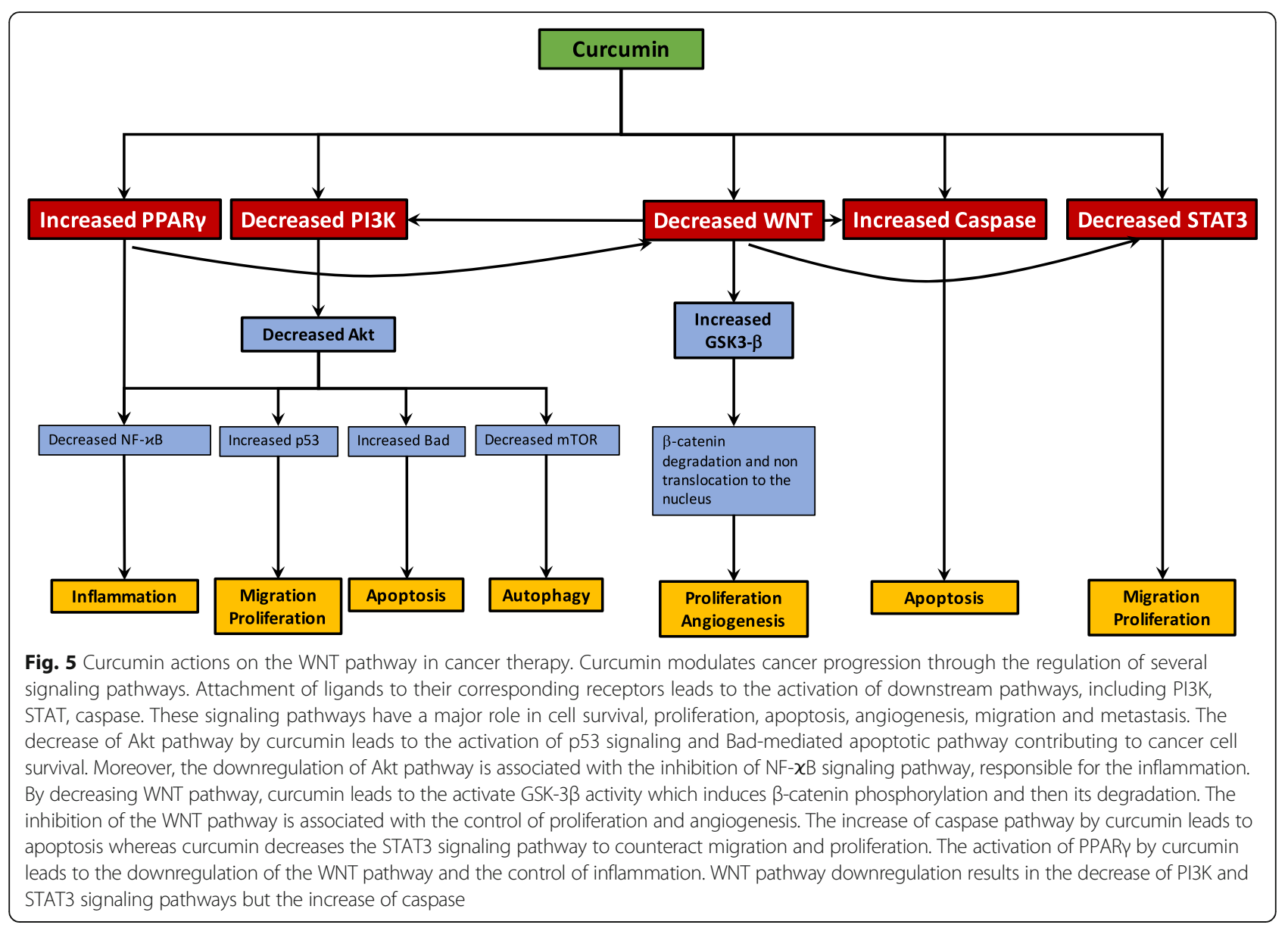

Curcumin inhibits the canonical WNT/ $\beta$-catenin pathway (Fig. 5) Cell-cycle is arrested in G2/M step in medulloblastoma cells by using curcumin inhibiting the $\mathrm{WNT} / \beta$-catenin pathway [165]. Curcumin directly stimulates GSK-3 $\beta$ activity leading to the loss of nuclear $\beta$-catenin level and thus the inactivation of cyclin D1. In osteosarcoma cells, curcumin analogs disrupt $\beta$-catenin nuclear translocation [166]. In the 43-existing analog of curcumin, 6 analogs present a more potent activity compared to curcumin in the inhibition of the WNT pathway. Curcumin downregulates the 12-0-tetradecanoylphorbol-13-acetate (TPA)-induced WNT pathway in xenograft mice models [167]. Curcumin and its analog (CHC007) inhibit $\beta$-catenin/ TCF/LEF complex in both colon, gastric, intestinal cancer cells [168]. Moreover, curcumin increases GSK-3 $\beta$ mRNA level in DAOY cells of medulloblastoma and thus downregulates the WNT/ $\beta$-catenin pathway [169]. Through the inhibition of the $\mathrm{WNT} / \beta$-catenin pathway, curcumin inhibits cyclin D1 and participates to the repression of the development and proliferation of gliomas [169].

\section{Curcumin inhibits Akt pathway (Fig. 5)}

In Burkitt's lymphoma cells, curcumin increases radiationinduced apoptosis through the inhibition of the PI3K/Akt pathway [170]. Moreover, the efficacy of curcumin is equivalent to Akt-specific inhibitors, such as LY294002 for PI3K and SH-5 for Akt. In prostatic cancer, curcumin directly targets the PI3K/Akt pathway [171]. The combination of curcumin with the PI3K-specific inhibitor LY294002 has shown a beneficial effect by increasing the inhibition of Bcl-2 protein [172].

\section{Curcumin stimulates PPARY (Fig. 5)}

Few studies have reported the PPAR $\gamma$ agonist role of curcumin. However, curcumin is known to induce apoptosis, and to inhibit cell proliferation and inflammation by stimulating PPAR $\gamma$ [173]. Through the activation of PPARy, curcumin inhibits tumor growth by downregulating cyclin D1 and EGFR expression [174]. In parallel, the inhibition of EGFR signaling by curcumin is associated with the increase of PPAR $\gamma$ expression in hepatic stellate cell of rats [175].

\section{Curcumin and inflammation (Fig. 6)}

Several studies have suggested that curcumin can alleviate oxidative stress and inflammation through the Nrf2keap1 pathway [176]. In various cancer cells, curcumin decreases pro-inflammatory signaling related and then 


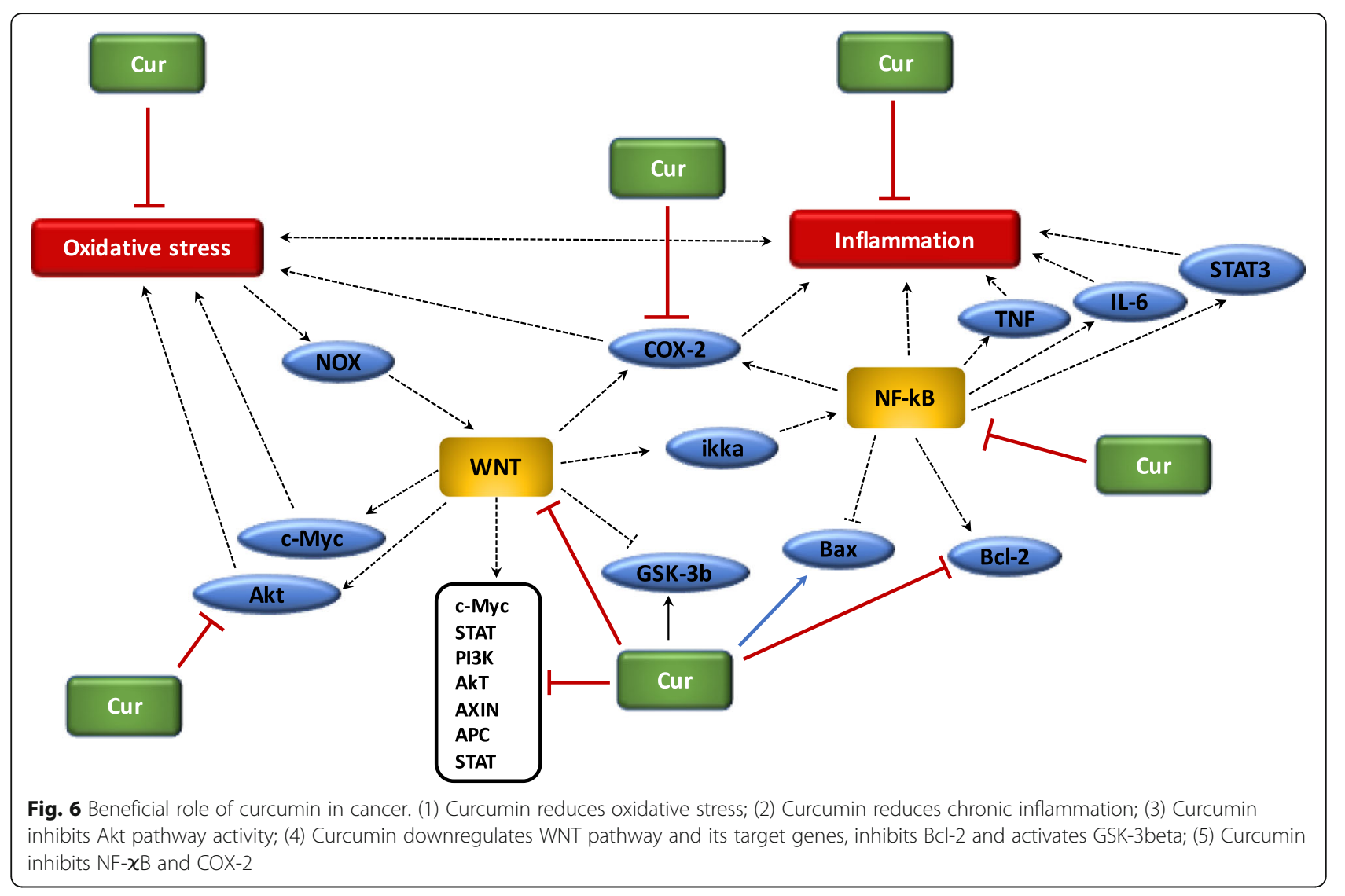

inhibits the activation of TNF- $\alpha$ [177]. Moreover, curcumin decreases the release of different interleukins by acting on the NF- $\mathrm{kB}$ pathway. Curcumin acts as a stress response mimetic which leads to many compounds of the protein homeostasis network [178]. Curcumin present several clinical therapeutic potentials in many type of cancer cells [179]. Curcumin acts as a modulator of cellular pathways on multiple targets which control tumor growth, angiogenesis, metastasis, inflammation, and apoptosis [180].

Cancer process is responsible for the activation of the NF- $\mathrm{kB}$ pathways leading to the over-expression of pro-inflammatory factors, including COX-2, iNOS, cytokines, TNF- $\alpha$ [181]. Curcumin presents an anti-proliferative role thought the inhibition of the NF- $\mathrm{kB}$ and its downstream genes, such as p53, VEGF, Bcl-2, COX-2, NOS, cyclin D1, TNF- $\alpha$, interleukins and MMP-9) [182]. Curcumin is considered as an interesting therapeutic way in melanoma cells through the inhibition of NF- $\varkappa$ B, STAT3 and COX-2 pathways [183]. Curcumin inhibits pro-inflammatory cytokines CXL1 and CXCL2 to decrease the formation of prostatic and breast metastases [184]. Curcumin inhibits the HPV-16-induced viral oncogenesis in oral tumor cell lines. Curcumin induces the blockage of the DNA-binding capacity of NF- $x \mathrm{~B}$ through the alteration of its subunits from p50/p50 to p50/p65. The suppression of the NF- $x B$ activity by curcumin is associated with the downregulation of AP-1 families of transcription factors [185]. Moreover, in mouse melanoma cells, curcumin induces the activation of the caspase- 3 and the dose-dependent inhibition of the $\mathrm{NF}-\varkappa \mathrm{B}$ activity and thus the inhibition COX-2 and cyclinD1 expression [186].

\section{Curcumin and oxidative stress (Fig. 6)}

Recent findings have shown that curcumin presents antiinflammatory effects mediated by the inactivation of the NF- $\varkappa$ B pathway [187], but rather on its oxidized products [188]. Oxidative metabolites of curcumin inhibit IKK. Treatment with $N$-acetylcysteine, a biosynthetic precursor of glutathione (GSH), the effect of curcumin was decreased, probably due to GSH-mediated scavenge and thus inactivating of curcumin-derived electrophile [188]. Oxidative stress, observed in cancer process, is based on the hypothesis of chronic inflammation [189]. The recent anti-tumorigenic role of curcumin in human leukemic cells may confirmed the presence of oxidized curcumin metabolites [188]. Indeed, curcumin is known to be a natural component presenting antioxidant effects [190]. Due to its chemical structure, curcumin is indeed a scavenger of ROS and RNS [191]. In addition, curcumin is a lipophilic compound, which makes it an efficient collector of peroxyl radicals. Curcumin controls the activity of GSH, catalase, and SOD enzymes activated in the neutralization 
of free radicals. Curcumin decreases ROS-generating enzymes such as lipoxygenase/cyclooxygenase and xanthine hydrogenase/ oxidase [192]. Inhibition of oxidative-stress induced DNA damage has been shown in curcumin treated mouse fibroblast cells [193]. In the leukemic cells, curcumin directly targets Nrf2 to downregulate ROS production [194].

\section{Curcumin and circadian rhythms}

Few studies have investigated the role of curcumin with circadian clock in cancers [195]. However, Bmal1 appears to be a target of curcumin through the stimulation of PPAR $\gamma[27,196]$. Curcumin activates sirtuin 1 (SIRT1) which regulates circadian rhythms. SIRT1 indirectly modulates circadian clock through the downregulation of NF- $x$ B [197], the inhibition of nuclear localization of Per2 [198] and the binding to Clock/Bmal1 [199].

\section{Relevance of "chronotherapy" in cancer clinical therapy}

The numerous interactions between clock dysregulation and cancer underline the interest of circadian therapeutic actions [26]. The temporal peak of cell activity could be targeted by pharmacological drugs used at an optimal time of day. Few studies have focused on the potential role of WNT and PPAR $\gamma$ with circadian clocks in cancer development. Nevertheless, interest in the association between PPAR $\gamma$ agonists and melatonin in cancer therapy is not new [200]. In cultured cells, the addition of melatonin with a PPAR $\gamma$ agonist (such as troglitazone) is associated with a significant reduction in cell numbers [201]. Moreover, other studies have shown a potent apoptotic effect of a combination of melatonin with PPAR $\gamma$ agonists in breast cancer cells [202, 203]. In parallel, recent studies have shown that melatonin could inhibit WNT pathway expression [204, 205].

In mouse ovaries, melatonin administration protects against ROS production and mitochondrial damage [206]. In colorectal cancer, the combination of 5-fluorouracil and melatonin is associated with the inhibition of cell proliferation through suppression of the PI3K/Akt pathway, NF- $\varkappa$ B pathway and nitric oxide synthase signaling [207]. Moreover, melatonin inhibits GSK3- $\beta$ to stop invasion in breast cancer cells [208]. The link between carcinogenesis and the circadian clock remains complex and difficult to unravel. Strong evidence suggests the involvement of the circadian clock in cancer development. Numerous molecular pathways are dynamically circadian, such as the $\mathrm{WNT} / \beta$-catenin pathway and PPAR $\gamma$. Thus, the time at which these pathways are targeted may be critical. Curcumin, by acting as PPAR $\gamma$ agonists and focusing on the $\mathrm{WNT} / \beta$-catenin pathway, should be used in concordance with the circadian clock genes, and therefore administered at the optimum time of day. Further studies should focus on the importance of the day/night cycle in cancer therapy and the circadian profiles of cancer cells.

\section{Conclusion}

Cancers are associated with chronic inflammation, oxidative stress and circadian clock disruption. The over-activation of the $\mathrm{WNT} / \beta$-catenin pathway increases these pathological phenomena. In cancers, the $\mathrm{WNT} / \beta$-catenin pathway is upregulated whereas PPAR $\gamma$ is downregulated. These two signaling pathways act in opposing manners and this could explain their unidirectional profile observed in cancers. Moreover, in cancers, the disruption of circadian clock leads to the increase of the WNT/ $\beta$-catenin pathway and to decrease of PPARy expression. The strongly link between circadian rhythms, chronic inflammation and oxidative stress appears to be a major mechanism underlying cancers. The use of curcumin, which acts as PPARY agonists, could be interesting in the reduction of both chronic inflammation and oxidative stress, and in the control of circadian clock by inhibiting the $\mathrm{WNT} / \beta$-catenin pathway. Due to the considerable impact of cancers on mortality and morbidity rates worldwide, it would appear of the utmost importance to better understand the action of curcumin in cancers and particularly its role in the inhibition of the major signaling system known as the $\mathrm{WNT} / \beta$-catenin pathway.

\section{Abbreviations \\ APC: Adenomatous polyposis coli; Bmal1: Brain and muscle aryl-hydrocarbon receptor nuclear translocator-like 1; CK1: Casein kinase 1; Clock: Circadian locomotor output cycles kaput; COX-2: Cyclooxygenase-2; CRD-BP: Coding Region Determinant-Binding Protein, an RNA-binding protein; CRs: Circadian rhythms; Cry: Cryptochrome; FZD: Frizzled; GSK-3ß: Glycogen synthase kinase-33; |xB-a: Nuclear factor of kappa light polypeptide gene enhancer in B-cells inhibitor, alpha; LRP 5/6: Low-density lipoprotein receptor-related protein 5/6; MAPK: Mitogen-activated protein kinases; NF- $x$ B: Nuclear factor $\chi B$; NOX: NADPH oxidase; Per: Period; PI3K-Akt: Phosphatidylinositol 3-kinase- protein kinase B; PPARY: Peroxisome proliferator-activated receptor gamma; RORs: Retinoid-related orphan receptors; ROS: Reactive oxygen species; \\ TCF/LEF: T-cell factor/lymphoid enhancer factor; TNF-a: Tumor necrosis factor alpha; $\beta \operatorname{TrCP}$ : Beta-transducin repeat-containing protein}

\section{Acknowledgements}

Not applicable.

Authors' contributions

All authors listed, have made substantial, direct and intellectual contribution to the work, and approved it for publication.

\section{Funding}

None.

Availability of data and materials Not applicable.

Ethics approval and consent to participate Not applicable.

Consent for publication

All the authors approved it for publication. 


\section{Competing interests}

The authors declare that the research was conducted in the absence of any commercial or financial relationship that could be construed as a potential conflict of interest.

\section{Author details}

'Diagnosis and Therapeutic Center, Hypertension and Cardiovascular Prevention Unit, Hotel-Dieu Hospital, AP-HP, Université Paris Descartes, 1 place du Parvis de Notre-Dame, Paris, France. ${ }^{2}$ Centre de Recherche Clinique, Grand Hôpital de l'Est Francilien (GHEF), 6-8 rue Saint-fiacre, 77100 Meaux, France. ${ }^{3}$ Centre Hospitalier Universitaire (CHU) Amiens Picardie, Université Picardie Jules Verne (UPJV), 80054 Amiens, France. ${ }^{4}$ Laboratoire de Mathématiques et Applications (LMA), UMR CNRS 7348, Université de Poitiers, Poitiers, France.

Received: 3 June 2019 Accepted: 10 July 2019

Published online: 22 July 2019

\section{References}

1. Ames BN, Gold LS. Animal cancer tests and cancer prevention. J Natl Cancer Inst Monogr. 1992;(12):125-32.

2. Guyton KZ, Kensler TW. Oxidative mechanisms in carcinogenesis. Br Med Bull. 1993:49:523-44.

3. Schulte-Hermann R, Timmermann-Trosiener I, Barthel G, Bursch W. DNA synthesis, apoptosis, and phenotypic expression as determinants of growth of altered foci in rat liver during phenobarbital promotion. Cancer Res. 1990; 50:5127-35.

4. Bartsch $\mathrm{H}$, Nair J. Chronic inflammation and oxidative stress in the genesis and perpetuation of cancer: role of lipid peroxidation, DNA damage, and repair. Langenbeck's Arch Surg. 2006:391:499-510.

5. Grivennikov SI, Greten FR, Karin M. Immunity, inflammation, and cancer. Cell. 2010;140:883-99.

6. Grivennikov SI, Karin M. Inflammation and oncogenesis: a vicious connection. Curr Opin Genet Dev. 2010;20:65-71.

7. Gonda TA, Tu S, Wang TC. Chronic inflammation, the tumor microenvironment and carcinogenesis. Cell Cycle Georget Tex. 2009;8:2005-13.

8. Coussens LM, Werb Z. Inflammation and cancer. Nature. 2002:420:860-7.

9. Mantovani A. Cancer: inflammation by remote control. Nature. 2005;435: 752-3.

10. Chung P-Y, Lam P-L, Zhou Y-Y, Gasparello J, Finotti A, Chilin A, et al. Targeting DNA binding for NF-KB as an anticancer approach in hepatocellular carcinoma. Cells. 2018;7(10). https://doi.org/10.3390/cells71 00177.

11. Reuter S, Gupta SC, Chaturvedi MM, Aggarwal BB. Oxidative stress, inflammation, and cancer: how are they linked? Free Radic Biol Med. 2010 49:1603-16.

12. Vallée A, Lecarpentier Y. Crosstalk between peroxisome proliferatoractivated receptor gamma and the canonical WNT/B-catenin pathway in chronic inflammation and oxidative stress during carcinogenesis. Front Immunol. 2018:9:745.

13. Yang D, Kim J. Mitochondrial retrograde Signalling and metabolic alterations in the tumour microenvironment. Cells. 2019;8. https://doi.org/1 0.3390/cells7100177.

14. Storz P. Reactive oxygen species in tumor progression. Front Biosci J Virtual Libr. 2005;10:1881-96.

15. Vallée A, Guillevin R, Vallée J-N. Vasculogenesis and angiogenesis initiation under normoxic conditions through Wnt/ $\beta$-catenin pathway in gliomas. Rev Neurosci. 2018;29:71-91.

16. Kasi PD, Tamilselvam R, Skalicka-Woźniak K, Nabavi SF, Daglia M, Bishayee A, et al. Molecular targets of curcumin for cancer therapy: an updated review. Tumour Biol J Int Soc Oncodevelopmental Biol Med. 2016;37:13017-28.

17. Nabavi SF, Daglia M, Moghaddam AH, Habtemariam S, Nabavi SM. Curcumin and liver disease: from chemistry to medicine. Compr Rev Food Sci Food Saf. 2014;13:62-77.

18. Ghosh S, Banerjee S, Sil PC. The beneficial role of curcumin on inflammation, diabetes and neurodegenerative disease: a recent update Food Chem Toxicol Int J Publ Br Ind Biol Res Assoc. 2015;83:111-24.

19. Sinha D, Biswas J, Sung B, Aggarwal BB, Bishayee A. Chemopreventive and chemotherapeutic potential of curcumin in breast cancer. Curr Drug Targets. 2012;13:1799-819.
20. Block Kl, Gyllenhaal C, Lowe L, Amedei A, Amin ARMR, Amin A, et al. Designing a broad-spectrum integrative approach for cancer prevention and treatment. Semin Cancer Biol. 2015;35(Suppl):S276-304.

21. Sgarbi G, Gorini G, Liuzzi F, Solaini G, Baracca A. Hypoxia and IF1 expression promote ROS decrease in Cancer cells. Cells. 2018;7. https://doi.org/10.3390/ cells7100177.

22. Thangapazham RL, Sharma A, Maheshwari RK. Multiple molecular targets in cancer chemoprevention by curcumin. AAPS J. 2006:8:E443-9.

23. Vallée A, Lecarpentier Y, Guillevin R, Vallée J-N. Opposite interplay between the canonical WNT/ $\beta$-catenin pathway and PPAR gamma: a potential therapeutic target in gliomas. Neurosci Bull. 2018;34(3):573-88.

24. Peters JM, Shah YM, Gonzalez FJ. The role of peroxisome proliferator-activated receptors in carcinogenesis and chemoprevention. Nat Rev Cancer. 2012;12:181-95.

25. Bandera Merchan B, Tinahones FJ, Macías-González M. Commonalities in the association between PPARG and vitamin D related with obesity and carcinogenesis. PPAR Res. 2016;2016:2308249.

26. Masri S, Sassone-Corsi P. The emerging link between cancer, metabolism, and circadian rhythms. Nat Med. 2018;24:1795-803.

27. Wang $N$, Yang G, Jia Z, Zhang $H$, Aoyagi T, Soodvilai S, et al. Vascular PPARgamma controls circadian variation in blood pressure and heart rate through Bmal1. Cell Metab. 2008:8:482-91.

28. Vallée A, Lecarpentier $Y$, Guillevin R, Vallée J-N. Thermodynamics in neurodegenerative diseases: interplay between canonical WNT/Beta-catenin pathway-PPAR gamma, Energy Metabolism and Circadian Rhythms. Neuromolecular Med. 2018;20(2):174-204.

29. Ledda A, Belcaro G, Dugall M, Luzzi R, Scoccianti M, Togni S, et al. Meriva ${ }^{\oplus}$, a lecithinized curcumin delivery system, in the control of benign prostatic hyperplasia: a pilot, product evaluation registry study. Panminerva Med. 2012;54:17-22.

30. Bayet-Robert M, Kwiatkowski F, Leheurteur M, Gachon F, Planchat E, Abrial $C$, et al. Phase I dose escalation trial of docetaxel plus curcumin in patients with advanced and metastatic breast cancer. Cancer Biol Ther. 2010;9:8-14.

31. Ghalaut VS, Sangwan L, Dahiya K, Ghalaut PS, Dhankhar R, Saharan R. Effect of imatinib therapy with and without turmeric powder on nitric oxide levels in chronic myeloid leukemia. J Oncol Pharm Pract Off Publ Int Soc Oncol Pharm Pract. 2012;18:186-90.

32. He Z-Y, Shi C-B, Wen H, Li F-L, Wang B-L, Wang J. Upregulation of p53 expression in patients with colorectal cancer by administration of curcumin. Cancer Investig. 2011:29:208-13.

33. Carroll RE, Benya RV, Turgeon DK, Vareed $S$, Neuman M, Rodriguez $L$, et al. Phase lla clinical trial of curcumin for the prevention of colorectal neoplasia. Cancer Prev Res Phila Pa. 2011;4:354-64.

34. Sharma RA, Euden SA, Platton SL, Cooke DN, Shafayat A, Hewitt HR, et al. Phase I clinical trial of oral curcumin: biomarkers of systemic activity and compliance. Clin Cancer Res Off J Am Assoc Cancer Res. 2004;10:6847-54.

35. Gou M, Men K, Shi H, Xiang M, Zhang J, Song J, et al. Curcumin-loaded biodegradable polymeric micelles for colon cancer therapy in vitro and in vivo. Nanoscale. 2011:3:1558-67.

36. Dhillon N, Aggarwal BB, Newman RA, Wolff RA, Kunnumakkara AB, Abbruzzese $J$, et al. Phase II trial of curcumin in patients with advanced pancreatic cancer. Clin Cancer Res Off J Am Assoc Cancer Res. 2008;14:4491-9.

37. Epelbaum R, Schaffer M, Vizel B, Badmaev V, Bar-Sela G. Curcumin and gemcitabine in patients with advanced pancreatic cancer. Nutr Cancer. 2010:62:1137-41.

38. Kanai M, Otsuka Y, Otsuka K, Sato M, Nishimura T, Mori Y, et al. A phase I study investigating the safety and pharmacokinetics of highly bioavailable curcumin (Theracurmin) in cancer patients. Cancer Chemother Pharmacol. 2013;71:1521-30.

39. Ide H, Tokiwa S, Sakamaki K, Nishio K, Isotani S, Muto S, et al. Combined inhibitory effects of soy isoflavones and curcumin on the production of prostate-specific antigen. Prostate. 2010;70:1127-33.

40. Thangapazham RL, Puri A, Tele S, Blumenthal R, Maheshwari RK. Evaluation of a nanotechnology-based carrier for delivery of curcumin in prostate cancer cells. Int J Oncol. 2008:32:1119-23.

41. Ganta S, Amiji M. Coadministration of paclitaxel and curcumin in nanoemulsion formulations to overcome multidrug resistance in tumor cells. Mol Pharm. 2009;6:928-39.

42. Panahi Y, Saadat A, Beiraghdar F, Sahebkar A. Adjuvant therapy with bioavailability-boosted curcuminoids suppresses systemic inflammation and improves quality of life in patients with solid tumors: a randomized doubleblind placebo-controlled trial. Phytother Res PTR. 2014;28:1461-7.

43. Liu W, Zhai Y, Heng X, Che FY, Chen W, Sun D, et al. Oral bioavailability of curcumin: problems and advancements. J Drug Target. 2016;24:694-702. 
44. Zhang L, Zhu W, Yang C, Guo H, Yu A, Ji J, et al. A novel folate-modified self-microemulsifying drug delivery system of curcumin for colon targeting. Int J Nanomedicine. 2012;7:151-62.

45. Shen L, Liu C-C, An C-Y, Ji H-F. How does curcumin work with poor bioavailability? Clues from experimental and theoretical studies. Sci Rep. 2016;6:20872

46. Sun M, Su X, Ding B, He X, Liu X, Yu A, et al. Advances in nanotechnologybased delivery systems for curcumin. Nanomed. 2012;7:1085-100.

47. Naksuriya O, Okonogi S, Schiffelers RM, Hennink WE. Curcumin nanoformulations: a review of pharmaceutical properties and preclinical studies and clinical data related to cancer treatment. Biomaterials. 2014;35:3365-83.

48. Malam Y, Loizidou M, Seifalian AM. Liposomes and nanoparticles: nanosized vehicles for drug delivery in cancer. Trends Pharmacol Sci. 2009;30:592-9.

49. Lee W-H, Loo C-Y, Young PM, Traini D, Mason RS, Rohanizadeh R. Recent advances in curcumin nanoformulation for cancer therapy. Expert Opin Drug Deliv. 2014;11:1183-201

50. Hatefi A, Amsden B. Biodegradable injectable in situ forming drug delivery systems. J Control Release Off J Control Release Soc. 2002;80:9-28.

51. Yallapu MM, Jaggi M, Chauhan SC. Beta-Cyclodextrin-curcumin selfassembly enhances curcumin delivery in prostate cancer cells. Colloids Surf B Biointerfaces. 2010:79:113-25.

52. Anuja K, Roy S, Ghosh C, Gupta P, Bhattacharjee S, Banerjee B. Prolonged inflammatory microenvironment is crucial for pro-neoplastic growth and genome instability: a detailed review. Inflamm Res Off J Eur Histamine Res Soc Al. 2017;66:119-28.

53. Wu Y, Antony S, Meitzler JL, Doroshow JH. Molecular mechanisms underlying chronic inflammation-associated cancers. Cancer Lett. 2014;345: 164-73.

54. Roessner A, Kuester D, Malfertheiner P, Schneider-Stock R. Oxidative stress in ulcerative colitis-associated carcinogenesis. Pathol Res Pract. 2008;204:511-24.

55. Parkin DM, Bray F, Ferlay J, Pisani P. Global cancer statistics, 2002. CA Cancer J Clin. 2005:55:74-108.

56. Lin W-W, Karin M. A cytokine-mediated link between innate immunity, inflammation, and cancer. J Clin Invest. 2007;117:1175-83.

57. Charles KA, Kulbe H, Soper R, Escorcio-Correia M, Lawrence T, Schultheis A, et al. The tumor-promoting actions of TNF-alpha involve TNFR1 and IL-17 in ovarian cancer in mice and humans. J Clin Invest. 2009;119:3011-23.

58. Szlosarek P, Charles KA, Balkwill FR. Tumour necrosis factor-alpha as a tumour promoter. Eur J Cancer Oxf Engl 1990. 2006;42:745-50.

59. Tang Q, Li J, Zhu H, Li P, Zou Z, Xiao Y. Hmgb1-IL-23-IL-17-IL-6-Stat3 axis promotes tumor growth in murine models of melanoma. Mediat Inflamm. 2013;2013:713859.

60. Lu H, Ouyang W, Huang C. Inflammation, a key event in cancer development. Mol Cancer Res MCR. 2006:4:221-33.

61. Sobolewski C, Cerella C, Dicato M, Ghibelli L, Diederich M. The role of cyclooxygenase-2 in cell proliferation and cell death in human malignancies. Int J Cell Biol. 2010;2010:215158.

62. Federico A, Morgillo F, Tuccillo C, Ciardiello F, Loguercio C. Chronic inflammation and oxidative stress in human carcinogenesis. Int J Cancer. 2007;121:2381-6.

63. Bubici C, Papa S, Pham CG, Zazzeroni F, Franzoso G. The NF-kappaB-mediated control of ROS and JNK signaling. Histol Histopathol. 2006;21:69-80.

64. Herrero R, Castellsagué X, Pawlita M, Lissowska J, Kee F, Balaram P, et al. Human papillomavirus and oral cancer: the International Agency for Research on Cancer multicenter study. J Natl Cancer Inst. 2003:95:1772-83.

65. Yu H, Lee H, Herrmann A, Buettner R, Jove R. Revisiting STAT3 signalling in cancer: new and unexpected biological functions. Nat Rev Cancer. 2014;14: 736-46

66. Duracková Z. Some current insights into oxidative stress. Physiol Res. 2010; 59:459-69.

67. Jabs T. Reactive oxygen intermediates as mediators of programmed cell death in plants and animals. Biochem Pharmacol. 1999;57:231-45.

68. Poyton RO, Ball KA, Castello PR. Mitochondrial generation of free radicals and hypoxic signaling. Trends Endocrinol Metab TEM. 2009;20:332-40.

69. Weyemi U, Lagente-Chevallier O, Boufraqech M, Prenois F, Courtin F, Caillou $B$, et al. ROS-generating NADPH oxidase NOX4 is a critical mediator in oncogenic H-Ras-induced DNA damage and subsequent senescence. Oncogene. 2012:31:1117-29.

70. Debnath T, Kim DH, Lim BO. Natural products as a source of antiinflammatory agents associated with inflammatory bowel disease. Mol Basel Switz. 2013;18:7253-70.
71. Giudice A, Montella M. Activation of the Nrf2-ARE signaling pathway: a promising strategy in cancer prevention. BioEssays News Rev Mol Cell Dev Biol. 2006;28:169-81.

72. Khor TO, Huang M-T, Prawan A, Liu Y, Hao X, Yu S, et al. Increased susceptibility of Nrf2 knockout mice to colitis-associated colorectal cancer. Cancer Prev Res Phila Pa. 2008;1:187-91.

73. Lin M, Zhai X, Wang G, Tian X, Gao D, Shi L, et al. Salvianolic acid B protects against acetaminophen hepatotoxicity by inducing Nrf2 and phase II detoxification gene expression via activation of the PI3K and PKC signaling pathways. J Pharmacol Sci. 2015;127:203-10.

74. Dey A, Lakshmanan J. The role of antioxidants and other agents in alleviating hyperglycemia mediated oxidative stress and injury in liver. Food Funct. 2013:4:1148-84.

75. Rusyn I, Rose ML, Bojes HK, Thurman RG. Novel role of oxidants in the molecular mechanism of action of peroxisome proliferators. Antioxid Redox Signal. 2000;2:607-21.

76. Manning BD, Cantley LC. AKT/PKB signaling: navigating downstream. Cell. 2007;129:1261-74.

77. Loh KM, van Amerongen R, Nusse R. Generating cellular diversity and spatial form: Wnt signaling and the evolution of multicellular animals. Dev Cell. 2016;38:643-55.

78. Oren $\mathrm{O}, \mathrm{Smith} \mathrm{BD}$. Eliminating Cancer stem cells by targeting embryonic signaling pathways. Stem Cell Rev. 2017;13:17-23.

79. Ferrer-Lorente R, Bejar MT, Tous M, Vilahur G, Badimon L. Systems biology approach to identify alterations in the stem cell reservoir of subcutaneous adipose tissue in a rat model of diabetes: effects on differentiation potential and function. Diabetologia. 2014;57:246-56.

80. Escate R, Padro T, Borrell-Pages M, Suades R, Aledo R, Mata P, et al. Macrophages of genetically characterized familial hypercholesterolaemia patients show up-regulation of LDL-receptor-related proteins. J Cell Mol Med. 2017;21:487-99.

81. Ye B, Hou N, Xiao L, Xu Y, Boyer J, Xu H, et al. APC controls asymmetric Wnt/ $\beta$-catenin signaling and cardiomyocyte proliferation gradient in the heart. J Mol Cell Cardiol. 2015:89:287-96.

82. Ambacher KK, Pitzul KB, Karajgikar M, Hamilton A, Ferguson SS, Cregan SP. The JNK- and AKT/GSK3 $\beta$ - Signaling Pathways Converge to Regulate Puma Induction and Neuronal Apoptosis Induced by Trophic Factor Deprivation. Hetman M, editor. PLoS ONE. 2012;7:e46885.

83. Tao H, Yang J-J, Shi K-H, Li J. Wht signaling pathway in cardiac fibrosis: new insights and directions. Metabolism. 2016;65:30-40.

84. $\mathrm{Ma} \mathrm{B}$, Hottiger MO. Crosstalk between Wnt/B-catenin and NF-KB signaling pathway during inflammation. Front Immunol. 2016;7:378.

85. Spiegelman VS, Slaga TJ, Pagano M, Minamoto T, Ronai Z, Fuchs SY. Wnt/ beta-catenin signaling induces the expression and activity of betaTrCP ubiquitin ligase receptor. Mol Cell. 2000;5:877-82.

86. Noubissi FK, Elcheva I, Bhatia N, Shakoori A, Ougolkov A, Liu J, et al. CRD-BP mediates stabilization of betaTrCP1 and c-myc mRNA in response to betacatenin signalling. Nature. 2006;441:898-901.

87. Jia D, Yang W, Li L, Liu H, Tan Y, Ooi S, et al. $\beta$-Catenin and NF-kB coactivation triggered by TLR3 stimulation facilitates stem cell-like phenotypes in breast cancer. Cell Death Differ. 2015:22:298-310.

88. Vallée A, Lecarpentier Y, Vallée J-N. Hypothesis of opposite interplay between the canonical WNT/beta-catenin pathway and PPAR gamma in primary central nervous system lymphomas. Curr Issues Mol Biol. 2019;31:120.

89. Phelps RA, Broadbent TJ, Stafforini DM, Jones DA. New perspectives on APC control of cell fate and proliferation in colorectal cancer. Cell Cycle Georget Tex. 2009;8:2549-56

90. Kuphal S, Poser I, Jobin C, Hellerbrand C, Bosserhoff AK. Loss of E-cadherin leads to upregulation of NFkappaB activity in malignant melanoma. Oncogene. 2004;23:8509-19.

91. Bandino A, Compagnone A, Bravoco V, Cravanzola C, Lomartire A, Rossetto $C$, et al. Beta-catenin triggers nuclear factor kappaB-dependent upregulation of hepatocyte inducible nitric oxide synthase. Int J Biochem Cell Biol. 2008;40:1861-71.

92. Schön S, Flierman I, Ofner A, Stahringer A, Holdt LM, Kolligs FT, et al. BCatenin regulates NF-KB activity via TNFRSF19 in colorectal cancer cells. Int $J$ Cancer. 2014;135:1800-11.

93. Ma B, Zhong L, van Blitterswijk CA, Post JN, Karperien M. T cell factor 4 is a pro-catabolic and apoptotic factor in human articular chondrocytes by potentiating nuclear factor KB signaling. J Biol Chem. 2013;288:17552-8. 
94. Saegusa M, Hashimura M, Kuwata T, Hamano M, Okayasu I. Crosstalk between NF-kappaB/p65 and beta-catenin/TCF4/p300 signalling pathways through alterations in GSK-3beta expression during trans-differentiation of endometrial carcinoma cells. J Pathol. 2007;213:35-45.

95. Buss H, Dörrie A, Schmitz ML, Frank R, Livingstone M, Resch K, et al. Phosphorylation of serine 468 by GSK-3beta negatively regulates basal p65 NF-kappaB activity. J Biol Chem. 2004;279:49571-4.

96. Schwitalla S, Fingerle AA, Cammareri P, Nebelsiek T, Göktuna SI, Ziegler PK, et al. Intestinal tumorigenesis initiated by dedifferentiation and acquisition of stem-cell-like properties. Cell. 2013;152:25-38.

97. Lamberti C, Lin KM, Yamamoto Y, Verma U, Verma IM, Byers S, et al. Regulation of beta-catenin function by the IkappaB kinases. J Biol Chem. 2001:276:42276-86.

98. Albanese C, Wu K, D'Amico M, Jarrett C, Joyce D, Hughes J, et al. IKKalpha regulates mitogenic signaling through transcriptional induction of cyclin D1 via Tcf. Mol Biol Cell. 2003;14:585-99.

99. Carayol N, Wang C-Y. IKKalpha stabilizes cytosolic beta-catenin by inhibiting both canonical and non-canonical degradation pathways. Cell Signal. 2006; 18:1941-6.

100. Shankar E, Weis MC, Avva J, Shukla S, Shukla M, Sreenath SN, et al. Complex systems biology approach in connecting PI3K-Akt and NF-KB pathways in prostate Cancer. Cells. 2019;8. https://doi.org/10.3390/cells7100177.

101. Plas DR, Thompson CB. Akt-dependent transformation: there is more to growth than just surviving. Oncogene. 2005;24:7435-42.

102. Covey TM, Edes K, Coombs GS, Virshup DM, Fitzpatrick FA. Alkylation of the tumor suppressor PTEN activates Akt and $\beta$-catenin signaling: a mechanism linking inflammation and oxidative stress with cancer. PLoS One. 2010;5:e13545.

103. Vallée A, Lecarpentier Y, Guillevin R, Vallée J-N. Thermodynamics in gliomas: interactions between the canonical WNT/Beta-catenin pathway and PPAR gamma. Front Physiol. 2017:8:352.

104. Vallée A, Guillevin R, Vallée J-N. Vasculogenesis and angiogenesis initiation under normoxic conditions through Wnt/B-catenin pathway in gliomas. Rev Neurosci. 2017;29(1):71-91.

105. Zhang D-Y, Pan Y, Zhang C, Yan B-X, Yu S-S, Wu D-L, et al. Wnt/B-catenin signaling induces the aging of mesenchymal stem cells through promoting the ROS production. Mol Cell Biochem. 2013;374:13-20.

106. Weinberg F, Hamanaka R, Wheaton WW, Weinberg S, Joseph J, Lopez M, et al. Mitochondrial metabolism and ROS generation are essential for Krasmediated tumorigenicity. Proc Natl Acad Sci U S A. 2010;107:8788-93.

107. Vafa O, Wade M, Kern S, Beeche M, Pandita TK, Hampton GM, et al. C-Myc can induce DNA damage, increase reactive oxygen species, and mitigate p53 function: a mechanism for oncogene-induced genetic instability. Mol Cell. 2002:9:1031-44.

108. Ahmadian M, Suh JM, Hah N, Liddle C, Atkins AR, Downes M, et al. PPARY signaling and metabolism: the good, the bad and the future. Nat Med. 2013;19:557-66.

109. Elbrecht A, Chen Y, Cullinan CA, Hayes N, Md L, Moller DE, et al. Molecular cloning, expression and characterization of human peroxisome proliferator activated receptors gamma 1 and gamma 2. Biochem Biophys Res Commun. 1996:224:431-7.

110. Ricote M, Glass CK. PPARs and molecular mechanisms of transrepression. Biochim Biophys Acta. 1771;2007:926-35.

111. Novellasdemunt L, Antas P, Li VSW. Targeting Wnt signaling in colorectal cancer. A review in the theme: cell signaling: proteins, pathways and mechanisms. Am J Physiol Cell Physiol. 2015;309:C511-21.

112. Liu J, Wang H, Zuo Y, Farmer SR. Functional interaction between peroxisome proliferator-activated receptor gamma and beta-catenin. Mol Cell Biol. 2006;26:5827-37.

113. Ohta T, Elnemr A, Yamamoto M, Ninomiya I, Fushida S, Nishimura G-I, et al. Thiazolidinedione, a peroxisome proliferator-activated receptor-gamma ligand, modulates the E-cadherin/beta-catenin system in a human pancreatic cancer cell line, BxPC-3. Int J Oncol. 2002;21:37-42.

114. Ross SE, Hemati N, Longo KA, Bennett CN, Lucas PC, Erickson RL, et al. Inhibition of adipogenesis by Wnt signaling. Science. 2000;289:950-3.

115. Liu J-J, Dai X-J, Xu Y, Liu P-Q, Zhang Y, Liu X-D, et al. Inhibition of lymphoma cell proliferation by peroxisomal proliferator-activated receptor- $\gamma$ ligands via Wnt signaling pathway. Cell Biochem Biophys. 2012;62:19-27.

116. Guo F, Ren X, Dong Y, Hu X, Xu D, Zhou H, et al. Constitutive expression of PPARY inhibits proliferation and migration of gastric cancer cells and downregulates Wnt/ $\beta$-catenin signaling pathway downstream target genes TERT and ENAH. Gene. 2016;584:31-7.
117. Prost S, Relouzat F, Spentchian M, Ouzegdouh Y, Saliba J, Massonnet G, et al. Erosion of the chronic myeloid leukaemia stem cell pool by PPARY agonists. Nature. 2015;525:380-3.

118. Liu L, Yang $Z, X u Y, L i J, X u D$, Zhang $L$, et al. Inhibition of oxidative stresselicited AKT activation facilitates PPARY agonist-mediated inhibition of stem cell character and tumor growth of liver cancer cells. PLoS One. 2013;8: e73038.

119. Hogenesch JB, Gu YZ, Jain S, Bradfield CA. The basic-helix-loop-helix-PAS orphan MOP3 forms transcriptionally active complexes with circadian and hypoxia factors. Proc Natl Acad Sci U S A. 1998;95:5474-9.

120. Gekakis N, Staknis D, Nguyen HB, Davis FC, Wilsbacher LD, King DP, et al. Role of the CLOCK protein in the mammalian circadian mechanism. Science. 1998;280:1564-9.

121. Reppert SM, Weaver DR. Coordination of circadian timing in mammals. Nature. 2002;418:935-41.

122. Schibler U, Sassone-Corsi P. A web of circadian pacemakers. Cell. 2002;111: 919-22.

123. Ko CH, Takahashi JS. Molecular components of the mammalian circadian clock. Hum Mol Genet. 2006;15(2):R271-7.

124. Truong KK, Lam MT, Grandner MA, Sassoon CS, Malhotra A. Timing matters: circadian rhythm in Sepsis, obstructive lung disease, obstructive sleep apnea, and Cancer. Ann Am Thorac Soc. 2016;13:1144-54.

125. Savvidis C, Koutsilieris M. Circadian rhythm disruption in cancer biology. Mol Med Camb Mass. 2012;18:1249-60.

126. Gu X, Xing L, Shi G, Liu Z, Wang X, Qu Z, et al. The circadian mutation PER2(S662G) is linked to cell cycle progression and tumorigenesis. Cell Death Differ. 2012;19:397-405.

127. Lévi F, Zidani R, Misset JL. Randomised multicentre trial of chronotherapy with oxaliplatin, fluorouracil, and folinic acid in metastatic colorectal cancer. International Organization for Cancer Chronotherapy. Lancet Lond Engl. 1997;350:681-6.

128. Coudert B, Focan C, Genet D, Giacchetti S, Cvickovic F, Zambelli A, et al. A randomized multicenter study of optimal circadian time of vinorelbine combined with chronomodulated 5-fluorouracil in pretreated metastatic breast cancer patients: EORTC trial 05971. Chronobiol Int. 2008;25:680-96.

129. Bertheault-Cvitkovic F, Lévi F, Soussan S, Brienza S, Adam R, Itzhaki M, et al. Circadian rhythm-modulated chemotherapy with high-dose 5-fluorouracil: a pilot study in patients with pancreatic adenocarcinoma. Eur J Cancer Oxf Engl 1990. 1993;29A:1851-4.

130. Giacchetti S, Bjarnason G, Garufi C, Genet D, lacobelli S, Tampellini M, et al. Phase III trial comparing 4-day chronomodulated therapy versus 2-day conventional delivery of fluorouracil, leucovorin, and oxaliplatin as first-line chemotherapy of metastatic colorectal cancer: the European Organisation for Research and Treatment of Cancer chronotherapy group. J Clin Oncol Off J Am Soc Clin Oncol. 2006;24:3562-9.

131. Puram RV, Kowalczyk MS, de Boer CG, Schneider RK, Miller PG, McConkey M, et al. Core circadian clock genes regulate leukemia stem cells in AML. Cell. 2016;165:303-16.

132. Dong W-G, Mei Q, Yu J-P, Xu J-M, Xiang L, Xu Y. Effects of melatonin on the expression of iNOS and COX-2 in rat models of colitis. World J Gastroenterol. 2003;9:1307-11.

133. Deng W-G, Tang S-T, Tseng H-P, Wu KK. Melatonin suppresses macrophage cyclooxygenase-2 and inducible nitric oxide synthase expression by inhibiting p52 acetylation and binding. Blood. 2006;108:518-24.

134. Murakami Y, Yuhara K, Takada N, Arai T, Tsuda S, Takamatsu S, et al. Effect of melatonin on cyclooxygenase-2 expression and nuclear factor-kappa B activation in RAW264.7 macrophage-like cells stimulated with fimbriae of Porphyromonas gingivalis. Vivo Athens Greece. 2011;25:641-7.

135. Huang S-H, Cao X, Wei W. Melatonin decreases TLR3-mediated inflammatory factor expression via inhibition of NF-kappa B activation in respiratory syncytial virus-infected RAW264.7 macrophages. J Pineal Res. 2008:45:93-100

136. Lu J-J, Fu L, Tang Z, Zhang C, Qin L, Wang J, et al. Melatonin inhibits AP-2B/ hTERT, NF-KB/COX-2 and Akt/ERK and activates caspase/Cyto $C$ signaling to enhance the antitumor activity of berberine in lung cancer cells. Oncotarget. 2016;7:2985-3001.

137. Wu Y, Tang D, Liu N, Xiong W, Huang H, Li Y, et al. Reciprocal regulation between the circadian clock and hypoxia signaling at the genome level in mammals. Cell Metab. 2017;25:73-85.

138. Adamovich Y, Ladeuix B, Golik M, Koeners MP, Asher G. Rhythmic oxygen levels reset circadian clocks through HIF1a. Cell Metab. 2017;25:93-101. 
139. Peek CB, Levine DC, Cedernaes J, Taguchi A, Kobayashi Y, Tsai SJ, et al. Circadian clock interaction with HIF1a mediates oxygenic metabolism and anaerobic glycolysis in skeletal muscle. Cell Metab. 2017;25:86-92.

140. Zawilska JB, Skene DJ, Arendt J. Physiology and pharmacology of melatonin in relation to biological rhythms. Pharmacol Rep PR. 2009;61:383-410.

141. Reiter RJ, Tan DX, Manchester LC, Qi W. Biochemical reactivity of melatonin with reactive oxygen and nitrogen species: a review of the evidence. Cell Biochem Biophys. 2001;34:237-56.

142. León J, Acuña-Castroviejo D, Escames G, Tan D-X, Reiter RJ. Melatonin mitigates mitochondrial malfunction. J Pineal Res. 2005;38:1-9.

143. Proietti S, Cucina A, Minini M, Bizzarri M. Melatonin, mitochondria, and the cancer cell. Cell Mol Life Sci CMLS. 2017;74:4015-25.

144. Chen TL. Inhibition of growth and differentiation of osteoprogenitors in mouse bone marrow stromal cell cultures by increased donor age and glucocorticoid treatment. Bone. 2004;35:83-95.

145. Soták M, Sumová A, Pácha J. Cross-talk between the circadian clock and the cell cycle in cancer. Ann Med. 2014;46:221-32.

146. Guo B, Chatterjee S, Li L, Kim JM, Lee J, Yechoor VK, et al. The clock gene, brain and muscle Arnt-like 1, regulates adipogenesis via Wnt signaling pathway. FASEB J Off Publ Fed Am Soc Exp Biol. 2012;26:3453-63.

147. Janich P, Pascual G, Merlos-Suárez A, Batlle E, Ripperger J, Albrecht U, et al. The circadian molecular clock creates epidermal stem cell heterogeneity. Nature. 2011:480:209-14.

148. Lin F, Chen Y, Li X, Zhao Q, Tan Z. Over-expression of circadian clock gene Bmal1 affects proliferation and the canonical Wnt pathway in $\mathrm{NIH}-3 \mathrm{~T} 3$ cells. Cell Biochem Funct. 2013;31:166-72.

149. Sahar S, Sassone-Corsi P. Metabolism and cancer: the circadian clock connection. Nat Rev Cancer. 2009:9:886-96.

150. Yang X, Wood PA, Ansell CM, Ohmori M, Oh E-Y, Xiong Y, et al. Beta-catenin induces beta-TrCP-mediated PER2 degradation altering circadian clock gene expression in intestinal mucosa of ApcMin/+ mice. J Biochem (Tokyo). 2009; 145:289-97.

151. Sancar A, Lindsey-Boltz LA, Unsal-Kaçmaz K, Linn S. Molecular mechanisms of mammalian DNA repair and the DNA damage checkpoints. Annu Rev Biochem. 2004;73:39-85.

152. Yang G, Jia Z, Aoyagi T, McClain D, Mortensen RM, Yang T. Systemic PPARY deletion impairs circadian rhythms of behavior and metabolism. PLoS One. 2012;7:e38117.

153. Fontaine C, Dubois G, Duguay Y, Helledie T, Vu-Dac N, Gervois P, et al. The orphan nuclear receptor rev-Erbalpha is a peroxisome proliferator-activated receptor (PPAR) gamma target gene and promotes PPARgamma-induced adipocyte differentiation. J Biol Chem. 2003;278:37672-80.

154. Green CB, Douris N, Kojima S, Strayer CA, Fogerty J, Lourim D, et al. Loss of Nocturnin, a circadian deadenylase, confers resistance to hepatic steatosis and diet-induced obesity. Proc Natl Acad Sci U S A. 2007;104:9888-93.

155. Chen L, Yang G. PPARs integrate the mammalian clock and energy metabolism. PPAR Res. 2014;2014:653017.

156. Manel N, Unutmaz D, Littman DR. The differentiation of human $T(H)-17$ cells requires transforming growth factor-beta and induction of the nuclear receptor RORgammat. Nat Immunol. 2008;9:641-9.

157. Clark RB, Bishop-Bailey D, Estrada-Hernandez T, Hla T, Puddington L, Padula SJ. The nuclear receptor PPAR gamma and immunoregulation: PPAR gamma mediates inhibition of helper T cell responses. J Immunol Baltim Md 1950. 2000;164:1364-71.

158. Li W, Zhang Z, Zhang K, Xue Z, Li Y, Zhang Z, et al. Arctigenin suppress Th17 cells and ameliorates experimental autoimmune encephalomyelitis through AMPK and PPAR- $/$ ROR-yt signaling. Mol Neurobiol. 2016;53:5356-66.

159. Klotz L, Burgdorf S, Dani I, Saijo K, Flossdorf J, Hucke S, et al. The nuclear receptor PPAR gamma selectively inhibits Th17 differentiation in a T cell-intrinsic fashion and suppresses CNS autoimmunity. J Exp Med. 2009;206:2079-89.

160. Newman DJ, Cragg GM. Natural products as sources of new drugs over the 30 years from 1981 to 2010. J Nat Prod. 2012;75:311-35.

161. Chakraborty G, Jain S, Kale S, Raja R, Kumar S, Mishra R, et al. Curcumin suppresses breast tumor angiogenesis by abrogating osteopontin-induced VEGF expression. Mol Med Rep. 2008;1:641-6.

162. Yoysungnoen $P$, Wirachwong $P$, Changtam C, Suksamrarn A, Patumraj S. Anti-cancer and anti-angiogenic effects of curcumin and tetrahydrocurcumin on implanted hepatocellular carcinoma in nude mice. World J Gastroenterol. 2008;14:2003-9.

163. Valastyan S, Weinberg RA. Tumor metastasis: molecular insights and evolving paradigms. Cell. 2011;147:275-92.
164. Killian PH, Kronski E, Michalik KM, Barbieri O, Astigiano S, Sommerhoff CP, et al. Curcumin inhibits prostate cancer metastasis in vivo by targeting the inflammatory cytokines CXCL1 and -2. Carcinogenesis. 2012;33:2507-19.

165. Kim HJ, Park SY, Park OJ, Kim Y-M. Curcumin suppresses migration and proliferation of Hep3B hepatocarcinoma cells through inhibition of the Wnt signaling pathway. Mol Med Rep. 2013;8:282-6.

166. Leow P-C, Bahety P, Boon CP, Lee CY, Tan KL, Yang T, et al. Functionalized curcumin analogs as potent modulators of the Wnt/ $\beta$-catenin signaling pathway. Eur J Med Chem. 2014;71:67-80.

167. Kolb TM, Davis MA. The tumor promoter 12-O-tetradecanoylphorbol 13acetate (TPA) provokes a prolonged morphologic response and ERK activation in Tsc2-null renal tumor cells. Toxicol Sci Off J Soc Toxicol. 2004;81:233-42.

168. Balasubramanyam K, Varier RA, Altaf M, Swaminathan V, Siddappa NB, Ranga U, et al. Curcumin, a novel p300/CREB-binding protein-specific inhibitor of acetyltransferase, represses the acetylation of histone/ nonhistone proteins and histone acetyltransferase-dependent chromatin transcription. J Biol Chem. 2004;279:51163-71.

169. He M, Li Y, Zhang L, Li L, Shen Y, Lin L, et al. Curcumin suppresses cell proliferation through inhibition of the Wnt/ $\beta$-catenin signaling pathway in medulloblastoma. Oncol Rep. 2014;32:173-80.

170. Polivka J, Janku F. Molecular targets for cancer therapy in the PI3K/AKT/ mTOR pathway. Pharmacol Ther. 2014;142:164-75.

171. Yu S, Shen G, Khor TO, Kim J-H, Kong A-NT. Curcumin inhibits Akt/ mammalian target of rapamycin signaling through protein phosphatasedependent mechanism. Mol Cancer Ther. 2008;7:2609-20.

172. Akkoç Y, Berrak Ö, Arısan ED, Obakan P, Çoker-Gürkan A, Palavan-Ünsal N. Inhibition of PI3K signaling triggered apoptotic potential of curcumin which is hindered by $\mathrm{BCl}-2$ through activation of autophagy in MCF-7 cells. Biomed Pharmacother Biomedecine Pharmacother. 2015;71:161-71.

173. Kunnumakkara AB, Anand P, Aggarwal BB. Curcumin inhibits proliferation, invasion, angiogenesis and metastasis of different cancers through interaction with multiple cell signaling proteins. Cancer Lett. 2008;269:199-225.

174. Nelson KM, Dahlin JL, Bisson J, Graham J, Pauli GF, Walters MA. The essential medicinal chemistry of curcumin. J Med Chem. 2017;60:1620-37.

175. Zhou Y, Zheng S, Lin J, Zhang Q-J, Chen A. The interruption of the PDGF and EGF signaling pathways by curcumin stimulates gene expression of PPARgamma in rat activated hepatic stellate cell in vitro. Lab Investig J Tech Methods Pathol. 2007:87:488-98.

176. He Y, Yue Y, Zheng X, Zhang K, Chen S, Du Z. Curcumin, inflammation, and chronic diseases: how are they linked? Mol Basel Switz. 2015;20:9183-213.

177. Gupta SC, Tyagi AK, Deshmukh-Taskar P, Hinojosa M, Prasad S, Aggarwal BB. Downregulation of tumor necrosis factor and other proinflammatory biomarkers by polyphenols. Arch Biochem Biophys. 2014;559:91-9.

178. Giordano S, Darley-Usmar V, Zhang J. Autophagy as an essential cellular antioxidant pathway in neurodegenerative disease. Redox Biol. 2014;2:82-90.

179. Shehzad A, Lee J, Lee YS. Curcumin in various cancers. BioFactors Oxf Engl. 2013:39:56-68.

180. Sung B, Prasad S, Yadav VR, Aggarwal BB. Cancer cell signaling pathways targeted by spice-derived nutraceuticals. Nutr Cancer. 2012;64:173-97.

181. Aggarwal BB, Vijayalekshmi RV, Sung B. Targeting inflammatory pathways for prevention and therapy of cancer: short-term friend, long-term foe. Clin Cancer Res Off J Am Assoc Cancer Res. 2009;15:425-30.

182. Kunnumakkara AB, Diagaradjane $P$, Anand $P$, Harikumar KB, Kuzhuvelil HB, Deorukhkar A, et al. Curcumin sensitizes human colorectal cancer to capecitabine by modulation of cyclin D1, COX-2, MMP-9, VEGF and CXCR4 expression in an orthotopic mouse model. Int J Cancer. 2009;125:2187-97.

183. Marín YE, Wall BA, Wang S, Namkoong J, Martino JJ, Suh J, et al. Curcumin downregulates the constitutive activity of NF-kappaB and induces apoptosis in novel mouse melanoma cells. Melanoma Res. 2007;17:274-83.

184. Kronski E, Fiori ME, Barbieri O, Astigiano S, Mirisola V, Killian PH, et al. miR181b is induced by the chemopreventive polyphenol curcumin and inhibits breast cancer metastasis via down-regulation of the inflammatory cytokines CXCL1 and -2. Mol Oncol. 2014;8:581-95.

185. Mishra A, Kumar R, Tyagi A, Kohaar I, Hedau S, Bharti AC, et al. Curcumin modulates cellular AP-1, NF-kB, and HPV16 E6 proteins in oral cancer. Ecancermedicalscience. 2015;9:525.

186. Singh S, Aggarwal BB. Activation of transcription factor NF-kappa B is suppressed by curcumin (diferuloylmethane) [corrected]. J Biol Chem. 1995: 270:24995-5000

187. Philip S, Kundu GC. Osteopontin induces nuclear factor kappa B-mediated promatrix metalloproteinase-2 activation through I kappa B alpha /IKK 
signaling pathways, and curcumin (diferulolylmethane) down-regulates these pathways. J Biol Chem. 2003;278:14487-97.

188. Edwards RL, Luis PB, Varuzza PV, Joseph Al, Presley SH, Chaturvedi R, et al. The anti-inflammatory activity of curcumin is mediated by its oxidative metabolites. J Biol Chem. 2017;292:21243-52.

189. Liochev SI. Reactive oxygen species and the free radical theory of aging. Free Radic Biol Med. 2013;60:1-4.

190. Pellavio G, Rui M, Caliogna L, Martino E, Gastaldi G, Collina S, et al. Regulation of aquaporin functional properties mediated by the antioxidant effects of natural compounds. Int J Mol Sci. 2017;18. https://doi.org/10.3390/cells7100177.

191. Chilelli NC, Ragazzi E, Valentini R, Cosma C, Ferraresso S, Lapolla A, et al. Curcumin and Boswellia serrata modulate the Glyco-oxidative status and Lipo-oxidation in master athletes. Nutrients. 2016;8. https://doi.org/10.3390/cells7100177.

192. Hewlings SJ, Kalman DS. Curcumin: a review of its' effects on human health. Foods Basel Switz. 2017:6. https://doi.org/10.3390/cells7100177.

193. Shih CA, Lin JK. Inhibition of 8-hydroxydeoxyguanosine formation by curcumin in mouse fibroblast cells. Carcinogenesis. 1993;14:709-12.

194. Kujundžić RN, Stepanić V, Milković L, Gašparović AČ, Tomljanović M, Trošelj $\mathrm{KG}$. Curcumin and its potential for systemic targeting of Inflamm-aging and metabolic reprogramming in Cancer. Int J Mol Sci. 2019;20. https://www. mdpi.com/1422-0067/20/5/1180.

195. Sarma A, Sharma VP, Sarkar AB, Sekar MC, Samuel K, Geusz ME. The circadian clock modulates anti-cancer properties of curcumin. BMC Cancer. 2016;16:759.

196. Wang H-M, Zhao Y-X, Zhang S, Liu G-D, Kang W-Y, Tang H-D, et al. PPARgamma agonist curcumin reduces the amyloid-beta-stimulated inflammatory responses in primary astrocytes. J Alzheimers Dis JAD. 2010;20:1189-99.

197. Chung S, Yao H, Caito S, Hwang J-W, Arunachalam G, Rahman I. Regulation of SIRT1 in cellular functions: role of polyphenols. Arch Biochem Biophys. 2010;501:79-90.

198. Miki T, Xu Z, Chen-Goodspeed M, Liu M, Van Oort-Jansen A, Rea MA, et al. PML regulates PER2 nuclear localization and circadian function. EMBO J. 2012;31:1427-39.

199. Asher G, Gatfield D, Stratmann M, Reinke H, Dibner C, Kreppel F, et al. SIRT1 regulates circadian clock gene expression through PER2 deacetylation. Cell. 2008:134:317-28

200. Korkmaz A, Tamura H, Manchester LC, Ogden GB, Tan D-X, Reiter RJ. Combination of melatonin and a peroxisome proliferator-activated receptorgamma agonist induces apoptosis in a breast cancer cell line. J Pineal Res. 2009:46:115-6

201. Hansen MB, Nielsen SE, Berg K. Re-examination and further development of a precise and rapid dye method for measuring cell growth/cell kill. J Immunol Methods. 1989;119:203-10.

202. Crowe DL, Chandraratna RAS. A retinoid X receptor (RXR)-selective retinoid reveals that RXR-alpha is potentially a therapeutic target in breast cancer cell lines, and that it potentiates antiproliferative and apoptotic responses to peroxisome proliferator-activated receptor ligands. Breast Cancer Res BCR. 2004;6:R546-55.

203. Eck-Enriquez K, Kiefer TL, Spriggs LL, Hill SM. Pathways through which a regimen of melatonin and retinoic acid induces apoptosis in MCF-7 human breast cancer cells. Breast Cancer Res Treat. 2000;61:229-39.

204. Yu N, Sun Y-T, Su X-M, He M, Dai B, Kang J. Melatonin attenuates TGF $\beta 1$ induced epithelial-mesenchymal transition in lung alveolar epithelial cells. Mol Med Rep. 2016;14:5567-72.

205. Wu S-M, Lin W-Y, Shen C-C, Pan H-C, Keh-Bin W, Chen Y-C, et al. Melatonin set out to ER stress signaling thwarts epithelial mesenchymal transition and peritoneal dissemination via calpain-mediated C/EBP $\beta$ and NFKB cleavage. J Pineal Res. 2016;60:142-54.

206. Barberino RS, Menezes VG, Ribeiro AEAS, Palheta RC, Jiang X, Smitz JEJ, et al. Melatonin protects against cisplatin-induced ovarian damage in mice via the MT1 receptor and antioxidant activity. Biol Reprod. 2017;96:1244-55.

207. Gao Y, Xiao X, Zhang C, Yu W, Guo W, Zhang Z, et al. Melatonin synergizes the chemotherapeutic effect of 5 -fluorouracil in colon cancer by suppressing PI3K AKT and NF-KB/iNOS signaling pathways. J Pineal Res. 2017;62. https://doi. org/10.3390/cells7100177.

208. Mao L, Dauchy RT, Blask DE, Slakey LM, Xiang S, Yuan L, et al. Circadian gating of epithelial-to-mesenchymal transition in breast cancer cells via melatonin-regulation of GSK3ß. Mol Endocrinol Baltim Md. 2012;26:1808-20.

\section{Publisher's Note}

Springer Nature remains neutral with regard to jurisdictional claims in published maps and institutional affiliations.

Ready to submit your research? Choose BMC and benefit from:

- fast, convenient online submission

- thorough peer review by experienced researchers in your field

- rapid publication on acceptance

- support for research data, including large and complex data types

- gold Open Access which fosters wider collaboration and increased citations

- maximum visibility for your research: over $100 \mathrm{M}$ website views per year

At BMC, research is always in progress.

Learn more biomedcentral.com/submissions 